\title{
Daily variability of suspended particulate concentrations and yields and their effect on river particulates chemistry
}

\author{
MICHEL MEYBECK ${ }^{1} \&$ FLORENTINA MOATAR ${ }^{2}$ \\ 1 METIS (UMR 7619), CNRS, Université Pierre et Marie Curie, 4 place Jussieu, 75252 Paris Cedex 05, France \\ michel.meybeck@upmc.fr \\ 2 Laboratoire GéoHydrosystèmes Continentaux (GeHCO) - Université François Rabelais, Faculté des Sciences et \\ Techniques, Parc de Grandmont, 37200 Tours, France.
}

\begin{abstract}
Daily total suspended solids concentrations (TSS, $\left.\mathrm{mg} \mathrm{L}^{-1}\right)$, yields $\left(\mathrm{Y}, \mathrm{kg} \mathrm{day}^{-1} \mathrm{~km}^{-2}\right)$ and runoff (q, $\left.\mathrm{L} \mathrm{s}^{-1} \mathrm{~km}^{-2}\right)$ in world rivers are described by the median $\left(\mathrm{C}_{50}\right)$, the upper percentile $\left(\mathrm{C}_{99}\right)$, the dischargeweighted average concentrations $\left(\mathrm{C}^{*}\right)$, and by their corresponding yields $\left(\mathrm{Y}_{50}, \mathrm{Y}_{99}, \mathrm{Y}^{*}\right)$ and runoff $\left(\mathrm{q}^{*}, \mathrm{q}_{50}\right.$, $\mathrm{q}_{99}$ ). These intra-station descriptors range over two to six orders of magnitude at a given station. Inter-station variability is considered through three sets of dimensionless metrics: (i) $\mathrm{q}^{*} / \mathrm{q}_{50}, \mathrm{C}^{*} / \mathrm{C}_{50}$ and $\mathrm{Y}^{*} / \mathrm{Y}_{50}$, defining the general temporal variability indicators, and $\mathrm{q}_{99} / \mathrm{q}_{50}, \mathrm{C}_{99} / \mathrm{C}_{50}$ and $\mathrm{Y}_{99} / \mathrm{Y}_{50}$, defining the extreme variability indicators; (ii) river flow duration $\left(\mathrm{W}_{2}\right)$ and flux duration $\left(\mathrm{M}_{2}\right)$ in $2 \%$ of time; and (iii) the truncated rating curve exponent $\left(\mathrm{b}_{50 \text { sup }}\right)$ of the $\mathrm{C} v s \mathrm{q}$ relationship for the upper flows. The TSS and Y variability, measured on US, French and world rivers, are first explained by hydrological variability through the $b_{50 \text { sup }}$ metric, the variability amplifier, then by basin size, erodibility, relief and lake occurrence. Yield variability is the product of runoff variability $\times$ TSS variability. All metrics are considerably modified after river damming. The control of river particulate matter (RPM) composition by TSS or yields depends on the targeted component. For major elements ( $\mathrm{Al}, \mathrm{Fe}, \mathrm{Mn}, \mathrm{Ti}, \mathrm{Si}, \mathrm{Ca}, \mathrm{Mg}, \mathrm{Na}, \mathrm{K}$ ), the average RPM chemistry is not dependent on $\mathrm{C}^{*}$ and $\mathrm{Y}^{*}$ in most world hydroregions, except in the tropical hydrobelt where it is controlled by basin relief. By contrast, the particulate organic carbon content (POC, as a percentage of RPM) is inversely correlated to TSS concentrations for (i) intra-station measurements in any hydroregion, and (ii) inter-station average POC and TSS figures in world rivers. TSS controls heavy metal content (ppm) in highly contaminated basins (e.g. Cd in the Seine $v s$ the Rhone), and total metal concentration (ng/L) in all cases. Relations between RPM composition and TSS should be taken into account when assessing riverine fluxes, as ignoring them could lead to overestimation.
\end{abstract}

Key words world rivers; daily sediment loads; temporal variability; flux duration; major particulate elements; particulate organic carbon; cadmium

\section{INTRODUCTION}

Since the pioneering survey of the Mississippi by Humphrey \& Abbot (1861), who measured daily concentrations of total suspended solids (TSS, $\mathrm{mg} \mathrm{L}^{-1}$ ) and fluxes, river hydrologists have been familiar with the great temporal variability of TSS and how it is affected by river flow (Q). Regional studies in the USA (Meade \& Parker, 1986), the former Soviet Union and China, which started before World War II (Walling \& Webb, 1996), have established the great spatial variability of long-term annual sediment yields $\left(\mathrm{Y}^{*}, \mathrm{t} \mathrm{km}^{-2}\right.$ year $\left.^{-1}\right)$ at the global scale, controlled by climate, relief, basin size, lithology and damming (for a complete review see Milliman \& Farnworth, 2011).

Some sediment flux studies have focused on the daily variability of TSS or of daily yields (Y, $\mathrm{kg} \mathrm{day}^{-1} \mathrm{~km}^{-2}$ ) at individual stations within large river basins, e.g. the Mississippi (Horowitz, 2003). The temporality of riverine fluxes has been investigated mostly by river engineers and geographers through the integrative concept of sediment flux duration (ASCE, 1970; Walling, 1977; Dunne,1979; Meybeck et al., 2003; Moatar et al., 2013), little used by river hydrologists.

At the global scale, there are still few studies of daily TSS temporality (Meybeck et al., 2003), despite its obvious importance in terms of optimizing sediment flux and water quality surveys, and understanding river ecology and the chemical composition of river particulate matter (RPM). Geochemists working on RPM chemistry (Gordeev \& Lisitzin, 1978; Potter, 1978; Martin \& Meybeck, 1979; Canfield, 1997; Rachold,1999; Gaillardet et al., 1999, 2003; Gaiero et al., 2002; Savenko, 2007; Viers et al., 2008) have seldom considered how it is affected by TSS at the daily scale, with the noted exception of particulate organic carbon (Meybeck, 1982; Kao and Liu, 1999; Moreira-Turcq et al, 2003; Coynel et al., 2005) following the pioneering work of Malcom and Durum (1976) and of some long-term studies (Horowitz et al., 2001). Here, we therefore address the following questions: 
(1) How can daily concentrations of total suspended sediments (TSS) and yields (Y) be described by dimensionless indicators?

(2) What is the spatial range of these indicators and their relationship with the hydrological variability at the global scale?

(3) How is the chemical composition of river particulates influenced by daily TSS and by average yields in major world rivers?

(4) What is the impact of human activities on the daily temporality indicators (for TSS and Y) and on daily RPM chemistry (for heavy metals)?

We focus on medium to large river basins for which it is assumed that sub-daily variations can be ignored, as opposed to day-to-day variations. Unless specified, we have selected stations with limited damming impact on sediment fluxes.

\section{TEMPORAL VARIABIILITY OF DAILY RIVER TSS CONCENTRATIONS AND YIELDS}

Our datasets of daily TSS cover all continents, climate and relief types $(n=107$ stations, representing more than 750 years of daily records). The fine scale temporality at the day-to-day scale is first presented by three specific sets of dimensionless metrics measuring: (i) average and extreme variability, (ii) flux duration, (iii) the relationship between suspended solids and daily flow in high-flow periods, determined by long-term daily records. To this end, we looked at stations with records of daily sediment fluxes, 5 to 10 years in most cases, at the global scale (Meybeck et al., 2003) and for US and French rivers (Moatar et al., 2006, 2012; Moatar \& Meybeck, 2007; Meybeck \& Moatar, 2012), where detailed data sources can be found. Median basin area is $35000 \mathrm{~km}^{2}$ for the global set and $8060 \mathrm{~km}^{2}$ in the US/French set. From this database it is possible to make inter-station comparisons across most hydroregions of the world, as defined by Meybeck et al. (2012), with basin sizes ranging from $1000 \mathrm{~km}^{2}$ to 3.2 million $\mathrm{km}^{2}$. Finally, we look at the impact of river damming on these metrics through the example of the Colorado River.

\section{Range of mean TSS $\left(C^{*}\right)$ and yields $\left(Y^{*}\right)$ in medium to large rivers}

The flow-weighted averages of suspended sediment, termed here $\mathrm{C}^{*}$, and the mean annual yield $\left(\mathrm{Y}^{*}, \mathrm{t} \mathrm{km}^{-2}\right.$ year ${ }^{-1}, \mathrm{~kg} \mathrm{day}^{-1} \mathrm{~km}^{-2}$ ) are generated by summing daily sediment loads, divided by river flow and by basin area. These average figures are generally the only ones reported in world river databases, which focus on inter-station and inter-river comparisons (Meybeck \& Ragu, 1997; Milliman \& Farnworth, 2011). In our data set, the $\mathrm{C}^{*}$ and $\mathrm{Y}^{*}$ distributions are very representative of medium to large rivers, but not of smaller rivers $\left(<1000 \mathrm{~km}^{2}\right)$ (Table 1). The river basins cover all world hydrobelts, defined by river basin boundaries (Meybeck et al., 2012): the Boreal belt (BOR, mean temperatures $-10^{\circ} \mathrm{C}$ to $-1{ }^{\circ} \mathrm{C}$ ), the mid-latitude belt (MLT, 7 to $16^{\circ} \mathrm{C}$ ), the dry belt (DRY, q $<150 \mathrm{~mm}$ year ${ }^{-1}$, represented in the database by Central Asia, $5^{\circ} \mathrm{C}$ ), and the tropical belt (TRP, 22 to $26^{\circ} \mathrm{C}$, here combining subtropical and equatorial hydrobelts).

Average $\mathrm{C}^{*}$ ranges over more than three orders of magnitude, from less than $10 \mathrm{mg} \mathrm{L}^{-1}$ at lake outlets (the lacustrine Rhone at Geneva, the St Lawrence) to more than $10000 \mathrm{mg} \mathrm{L}^{-1}$ for the Huang He. The average yield ranges from $<5$ to more than $5000 \mathrm{t} \mathrm{year}^{-1} \mathrm{~km}^{-2}$, in the Somme and the Huang He (Yellow River), respectively (Table 1). $\mathrm{Y}^{*}$ is directly correlated to $\mathrm{C}^{*}$, although a great dispersion can be observed: for a given $\mathrm{C}^{*}$, yields vary over two orders of magnitude, depending on average runoff, represented by diagonals $\mathrm{q}=10,100$ and $1000 \mathrm{~mm}_{\text {year }}{ }^{-1}$ (Fig. 1(a)). Other variables, including relief, basin size, and occurrence of lakes and lithology, should also be considered (Milliman \& Syvitski, 1992; Milliman \& Farnworth, 2011).

\section{General $\left(C^{*} / \mathbf{C}_{50}\right)$ and extreme $\left(\mathbf{Y}_{99} / \mathbf{Y}_{50}\right)$ metrics of daily variability}

Daily TSS, sediment yields and runoff $\mathrm{q}$ are ranked to determine their percentile distribution from the $1^{\text {st }}$ to the $99^{\text {th }}$ percentile, including the 50th (median). The following variability indicators are then calculated: $\mathrm{q}^{*} / \mathrm{q}_{50}, \mathrm{C}^{*} / \mathrm{C}_{50}$, and $\mathrm{Y}^{*} / \mathrm{Y}_{50}$ for general daily variability, and $\mathrm{q}_{99} / \mathrm{q}_{50}, \mathrm{C}_{99} / \mathrm{C}_{50}$, and $\mathrm{Y}_{99} / \mathrm{Y}_{50}$ for extreme daily variability (Table 1 ). 
Table 1 TSS concentrations and yields in selected world rivers at the daily time scale. Indicators of general daily variability for runoff $\left(\mathrm{q}^{*} / \mathrm{q}_{50}\right)$, for TSS $\left(\mathrm{C}^{*} / \mathrm{C}_{99}\right)$ and yields $\left(\mathrm{Y}^{*} / \mathrm{Y}_{50}\right)$. Indicators of extreme variability $\left(\mathrm{q}_{99} / \mathrm{q}_{50} ; \mathrm{C}_{99} / \mathrm{C}_{50} ; \mathrm{Y}_{99} / \mathrm{Y}_{50}\right)$. River flow and sediment flux duration in $2 \%$ of time $\left(\mathrm{W}_{2}, \mathrm{M}_{2}\right)$. Rating curve exponent: truncated $b_{50 \text { sup }}$ or pseudo-rating exponent $\beta_{50-95}$.

\begin{tabular}{|c|c|c|c|c|c|c|c|c|c|c|c|c|c|c|c|}
\hline River & $\begin{array}{c}\mathrm{A} \\
\mathrm{km}^{2}\end{array}$ & $\begin{array}{c}\text { Period } \\
-\end{array}$ & $\begin{array}{l}\text { Period } \\
\text { years }\end{array}$ & $\begin{array}{c}\mathrm{q}_{*} \\
1 \mathrm{~s}^{-1} \mathrm{~km}^{2}\end{array}$ & $\begin{array}{c}\mathbf{q} / \mathbf{q}_{50} \\
-\end{array}$ & $\begin{array}{c}\mathbf{q}_{99} / \mathbf{q}_{50} \\
-\end{array}$ & $\begin{array}{c}\text { C. } \\
\mathrm{mg} / \mathrm{L}\end{array}$ & $\begin{array}{c}C_{*} / C_{50} \\
-\end{array}$ & $\mathrm{C}_{99} / \mathrm{C}_{50}$ & $\begin{array}{c}Y_{*} \\
t y^{-1} \mathrm{~km}^{-2}\end{array}$ & $\begin{array}{c}Y^{*} / Y_{50} \\
-\end{array}$ & $\begin{array}{c}Y_{99} / Y_{50} \\
-\end{array}$ & $\mathbf{b}_{50 \text { sup }}$ & $\begin{array}{c}\mathbf{M}_{\mathbf{2}} \\
\%\end{array}$ & $\begin{array}{l}\mathbf{W}_{2} \\
\%\end{array}$ \\
\hline Piray, Angustura, Bolivia & 1420 & & & 5.2 & 2.6 & & 4540 & 20.6 & & 744 & 45.3 & & 1.33\# & 78.6 & 25.4 \\
\hline$\boxminus$ Abib, Morocco & 2635 & 1995-1997 & 3 & 4.34 & 2.19 & & 11600 & 1.2 & & 1600 & 3.4 & & $0.54 \#$ & 23.5 & 20.9 \\
\hline Walla-Walla, OR (USA) & 4279 & $1962-1965$ & 3 & 3.87 & 1.95 & 14.9 & 7000 & 116.7 & 137.1 & 825 & 243 & 1813.6 & 1.96 & 92.6 & 27.7 \\
\hline Somme, Abbeville, France & 5560 & 1980-1997 & 18 & 6.5 & 1.02 & & 23 & 1.3 & & 4.7 & 1.3 & & 1.59 & 7.9 & 4.5 \\
\hline Rhone, Geneva, Sw itzerland & 7987 & 1971-1972 & 2 & 23.4 & 1.08 & & 5 & 1.4 & & 3.5 & 1.5 & & $1.7 \#$ & 10.8 & 3 \\
\hline Eel , Scotia, CA (USA) & 8060 & $1960-1979$ & 10 & 28.31 & 5.20 & 62.19 & 2988 & 272.7 & 438 & 7309 & 1604 & 25591 & 1.51 & 76.3 & 30.2 \\
\hline Oise, Mery, France & 16972 & 1995-2004 & 9 & 7.2 & 1.37 & 4.97 & 37 & 2.10 & 8 & 23 & 3 & 23 & 0.68 & 17.5 & 7.7 \\
\hline Delaw are, Trenton, NJ (USA) & 17553 & 1968-1981 & 13 & 20.5 & 1.46 & 6.68 & 56 & 6.23 & 32 & 99 & 9 & 161 & 1.37 & 54.9 & 9.9 \\
\hline San Juan, Shiprock, NM (USA) & 33400 & 1955-1985 & 30 & 1.68 & 1.46 & 7.85 & 3812 & 4.8 & 50 & 552 & 7.2 & 107 & $0.35 \#$ & 42.9 & 11.4 \\
\hline Gambia, Gouloumbou, Senegal & 42000 & 1983-1984 & 1 & 1.49 & 3.82 & & 45 & 3 & & 5.8 & 11.6 & & 0.59 & 22 & 11.6 \\
\hline Rhine, Maxau, Germany & 50196 & 1974-1992 & 18 & 25.6 & 1.09 & 2.54 & 29 & 1.44 & 5 & 64 & 2 & 11 & 1.13\# & 15.9 & 4.8 \\
\hline Salw een, Ban Mae Sam Laeb, Thailand & 260000 & 1996-1997 & 2 & 20 & 1.67 & & 994 & 5.9 & & 634 & 8.7 & & 1.79\# & 14 & 6.75 \\
\hline Peace, Peace Point, AL ( Canada) & 293000 & 1973-1975 & 3 & 6.6 & 1.16 & & 587 & 14.3 & & 122 & 19.8 & & 4.3\# & 38.2 & 5.6 \\
\hline Colorado, Grand Canyon, AZ (USA) & 366585 & 1931-1941 & 11 & 1.2 & 2 & 5.4 & 9557 & 2.27 & 13.1 & 393 & 4.2 & 35 & 0.17 & 20 & 11 \\
\hline Colorado, Grand Canyon, AZ ( USA) & 366585 & $1966-1972$ & 7 & 0.95 & 1.01 & 1.64 & 1122 & 3.3 & 47.2 & 39.2 & 3.63 & 53 & 1.7 & 10 & 3.4 \\
\hline Mekong, Mukdahan, Thailand & 391000 & 1996-1997 & 2 & 20.7 & 2.59 & & 584 & 6.1 & & 381 & 10.4 & & $1.17 \#$ & 20 & 8.3 \\
\hline St Law rence, Quebec, Canada & 1000000 & & & 12 & 1.08 & & 14 & 1.4 & & 5.2 & 1.5 & & 2\# & 16 & 4.1 \\
\hline Mississippi, Tabert Landing, LO (USA) & 3221000 & 1950- 1952 & 3 & 5.33 & 1.03 & & 849 & 1.1 & & 143 & 1.1 & & 0.92 & 6.3 & 4.7 \\
\hline
\end{tabular}
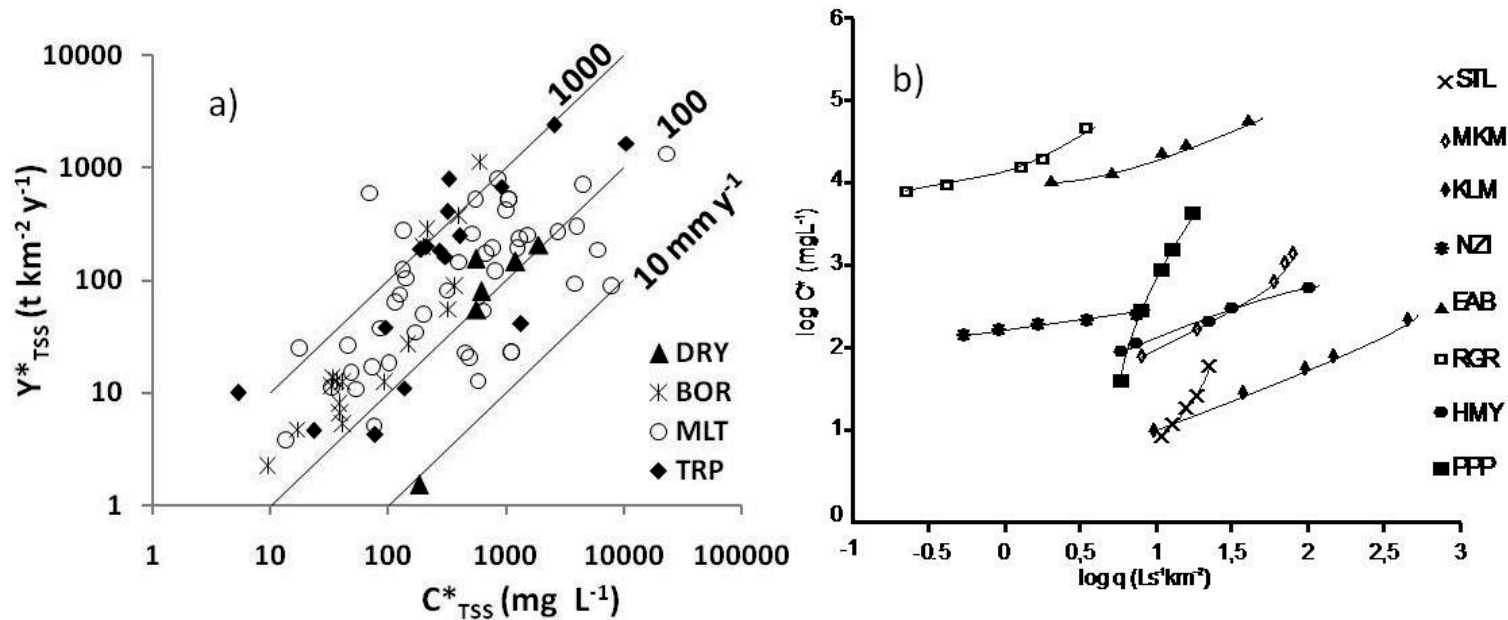

Fig. 1 Global scale distribution of average TSS concentrations $\left(C, \mathrm{mg} \mathrm{L}^{-1}\right)$ and yields $\left(\mathrm{Y}^{*}, \mathrm{t}^{-1} \mathrm{~km}^{-2}\right)$ in world rivers: (a) $\mathrm{Y}^{*}$ vs $\mathrm{C}^{*}$ as a function of average runoff (q, $\mathrm{mm}$ year-1) plotted as diagonals, for different world hydroregions. BOR: boreal; MLT: Mid-Latitude; DRY: dry; TRP: tropical and subtropical. Log-Log scales. (b) Comparison of $\mathrm{C} v s$ q relations by the pseudo-rating curve, established on quantiles $\left(\mathrm{C}_{50}, \mathrm{C}_{75}, \mathrm{C}_{90}, \mathrm{C}_{95}\right.$ and $\mathrm{C}_{99 \%} ; \mathrm{q}_{50}, \mathrm{q}_{75}, \mathrm{q}_{90}, \mathrm{q}_{95}$ and $\mathrm{q}_{99 \%}$, in $\left.\mathrm{L} \mathrm{s}^{-1} \mathrm{~km}^{-2}\right)$. STL: Saint Lawrence; MKM: Mekong (Mukdahan, Thailand); KLM: Khlong Mala (Thailand); NZI: Nzi (Ivory Coast); EAB: El Abib (Morocco); RGR: Rio Grande (USA-Mexico); HMY: Huay Mae Ya (Thailand); PPP: Peace (Canada). (Data from Meybeck et al., 2003).

The general variability indicators in medium to large river basins range from 1.1 to 273 for $\mathrm{C}^{*} / \mathrm{C}_{50}$ and from 1.1 to 1,604 for $\mathrm{Y}^{*} / \mathrm{Y}_{50}$. The discharge-weighted average TSS can be more than one order of magnitude greater than median TSS. The extreme variability indicator for TSS concentrations, the $\mathrm{C}_{99} / \mathrm{C}_{50}$ ratio, ranges from 4.9 to 558 (median 24 in the database). For the daily sediment yields, the extreme variability is much greater. At a given station, the $\mathrm{Y}_{99} / \mathrm{Y}_{50}$ ratio ranges from 10 to 32000 (median 178) for the global dataset, i.e. the upper daily yield or flux, exceeded on average four days per year, is commonly two orders of magnitude greater than the median yield; in some rivers it can exceed the median 10000 fold! The extreme flux variability, defined by the $Y_{99} / Y_{50}$ ratio is directly linked to the extreme flow variability, $q_{99} / q_{50}$, through the development of the $C v s q$ relationship: 


$$
\left(\log \left(\frac{Y_{99}}{Y_{50}}\right)\right)_{t_{h}}=\left(b_{50 \text { sup }}+1\right) \log \left(\frac{q_{99}}{q_{50}}\right)
$$

The variability indicators for daily yields, either $\mathrm{Y}^{*} / \mathrm{Y}_{50}$ or $\mathrm{Y}_{99} / \mathrm{Y}_{50}$, also correspond to the product of river flow variability $\left(\mathrm{q}^{*} / \mathrm{q}_{50}, q_{99} / q_{50}\right)$ times the TSS variability $\left(\mathrm{C}^{*} / \mathrm{C}_{50}, \mathrm{C}_{99} / \mathrm{C}_{50}\right)$ (Meybeck \& Moatar, 2012). The observed extreme flux variability presents a good fit with this theoretical variability across the range of Y (Fig. 2(b)).

For each dataset, $q_{99} / q_{50}$ is known and $b_{50 \text { sup }}$ can be estimated, allowing the calculation of theoretical $Y_{99} / Y_{50}$ ratio. The theoretical general variability indicator $\left(Y^{*} / Y_{50}\right)$ can also be calculated. It is, however, not linearly linked to $b_{50 \text { sup: }}$ :

$$
\left(\frac{Y^{*}}{Y_{50}}\right)_{\text {th }}=\frac{\sum_{i=1}^{n} q_{i}^{{ }_{50 \text { sup }}+1}}{n q_{50}^{{ }_{50 \text { sup }}+1}}
$$
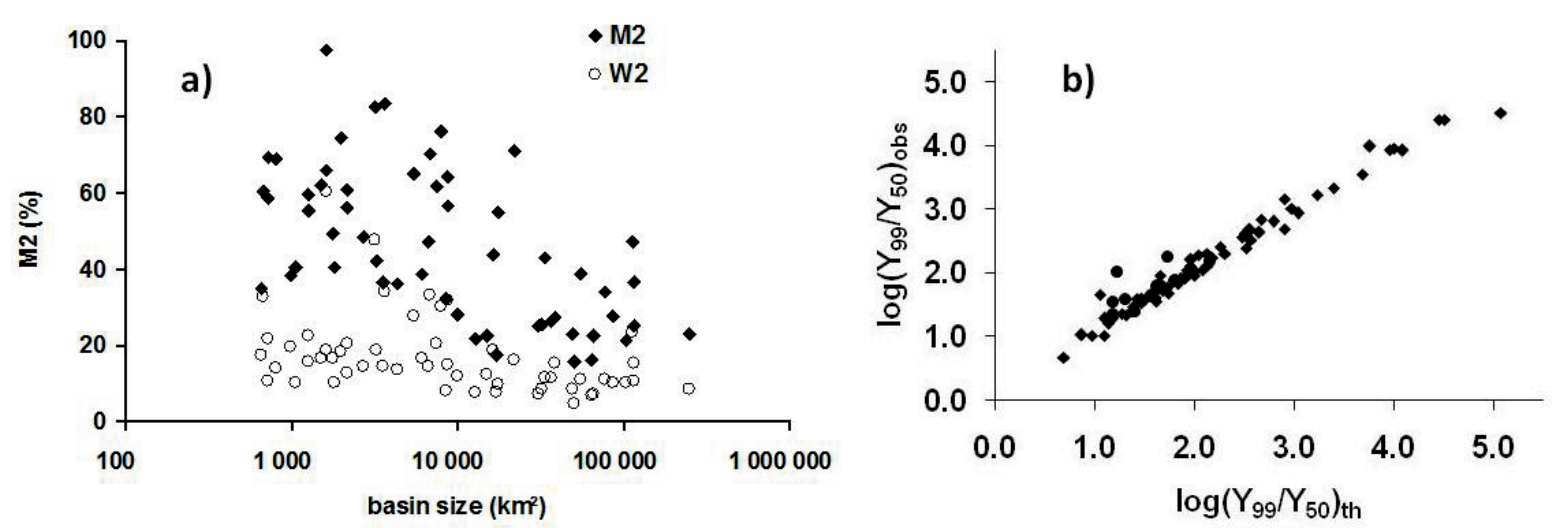

Fig. 2 Range of duration and of extreme sediment flux characteristics in world rivers: (a) Flow duration $\left(\mathrm{W}_{2}\right)$ and sediment flux duration $\left(\mathrm{M}_{2}\right)$ in $2 \%$ of time vs river basin size. (b) Observed extreme variability for daily yields $\left(\mathrm{Y}_{99} / \mathrm{Y}_{50}\right)$ vs theoretical variability (Meybeck et al., 2003; Meybeck \& Moatar, 2012).

All these daily variability indicators decrease with basin size (Meybeck et al., 2003; Meybeck \& Moatar, 2012). Other factors include erodibility of basin rocks and basin morphology (relief, lakes), rainfall regime, etc. These indicators should now be considered in our approach to global erosion and be included in global databases of sediment fluxes (Milliman \& Syvitski, 1992; Meybeck \& Ragu, 1996; Milliman \& Farnworth, 2011) which still focus on average sediment flux data, taken as such from the literature without proper information about their estimation (frequency of records, flux calculation methods, etc.), and do not address the temporal variability of fluxes.

\section{Sediment flux duration and its metrics $\left(\mathrm{W}_{2}, \mathrm{M}_{2}\right)$}

The flux duration curves, for river flow and sediments, are established from ranked daily runoff and daily suspended loads (Walling, 1977). Flows and fluxes are then cumulated from the highest to the lowest and summed. The percentages of river flow and sediment fluxes in $1 \%, 2 \%, 5 \% \ldots$ of time (e.g. 36, 73, 182 days over a 10-year period) determine the flow duration $\left(\mathrm{W}_{1}, \mathrm{~W}_{2}, \mathrm{~W}_{5}\right)$ and the sediment flux duration $\left(\mathrm{M}_{1}, \mathrm{M}_{2}, \mathrm{M}_{5}\right)$. The $\mathrm{M}_{2}$ indicator offers the best discrimination for the inter-station comparison of sediment flux duration. It is also convenient for the comparison of fluxes at a given station, for different riverine materials such as water, sediments, nutrients, and dissolved salts. It is also a key parameter for the assessment of flux uncertainties based on discrete sampling, as commonly performed in water quality surveys (Meybeck \& Moatar, 2012; Moatar et al., 2013; Raymond et al., 2013). 
Two extreme duration patterns are presented here for basins of similar size located at midlatitudes: the Somme (northern France), illustrating very low TSS variability and erosion intensity, and the Eel (North California, USA), an extreme example of TSS variability and erosion intensity (Syvitski \& Morehead, 1999). The Somme $\left(5560 \mathrm{~km}^{2}\right)$ is a typical phreatic river, the outlet of a major chalk aquifer with very low relief and limited rock erodibility. River flow variability, regulated by the aquifer, is very low considering the basin size: the $\mathrm{q}^{*} / \mathrm{q}_{50}$ ratio is only 1.02 , very close to that of very large basins like the Mississippi $\left(3.2 \times 10^{6} \mathrm{~km}^{2}\right)$. The Somme has a very low TSS level and erosion rate $\left(\mathrm{C}^{*}=23 \mathrm{mg} \mathrm{L}^{-1} ; \mathrm{Y}^{*}=4.7 \mathrm{t}\right.$ year $\left.{ }^{-1} \mathrm{~km}^{-2}\right)$, only found in basins with major lake influence (Table 1). Its general variability indicators are very low: $\mathrm{C}^{*} / \mathrm{C}_{50}$ ratio is 1.3 , also close to that of the Mississippi (1.1). The quantity of sediment carried in $2 \%$ of time $\left(\mathrm{M}_{2}\right)$ is very low, $7.9 \%$, and the related figure for river flow is also low, $4.5 \%$. The extreme variability indicators are also very modest in the Somme.

By contrast, the Eel River basin $\left(8063 \mathrm{~km}^{2}\right)$ in the coastal California mountain range, exposed to rare and intense rainstorms typical of the Mediterranean regime, has extreme daily variability for TSS and yields. The river sediment discharged in a few days can equal annual sediment load in the absence of extreme storms (Meade \& Parker, 1985; Syvitski \& Morehead, 1999). The median TSS is actually very low, $\mathrm{C}_{50}=11 \mathrm{mg} \mathrm{L}^{-1}$, but the weighted long-term average $\mathrm{C}^{*}$ reaches 1073 $\mathrm{mg} \mathrm{L}^{-1}$, and TSS peaks $\left(\mathrm{C}_{99}\right)$ exceed $10000 \mathrm{mg} \mathrm{L}^{-1}$. The general daily variability indicators are very high: $\mathrm{q}^{*} / \mathrm{q}_{50}=5.2, \mathrm{C}^{*} / \mathrm{C}_{50}=272, \mathrm{Y}^{*} / \mathrm{Y}_{50}=1604$, and the extreme daily variability indicators are several orders of magnitude higher: $\mathrm{q}_{99} / \mathrm{q}_{50}=62, \mathrm{C}_{99} / \mathrm{C}_{50}=438$, and $\mathrm{Y}_{99} / \mathrm{Y}_{50}=25600$. The flow and sediment duration indicators for $2 \%$ of time reach the maximum figures found in the database for this basin size: $\mathrm{W}_{2}=30.2 \%$ and $\mathrm{M}_{2}=76.2 \%$.

Flux duration patterns can be represented in a double probability plot, \% flux $v$ s $\%$ elapsed time. In Fig 3(a), TSS or other river-borne material durations are represented by quasi-parallel lines. TSS durations are greater than the flow duration, while total dissolved solids durations are lower (Moatar et al., 2013). The TSS durations of the Eel and the Somme are compared with those of the Delaware and the Oise, illustrating different duration patterns in middle-sized basins.
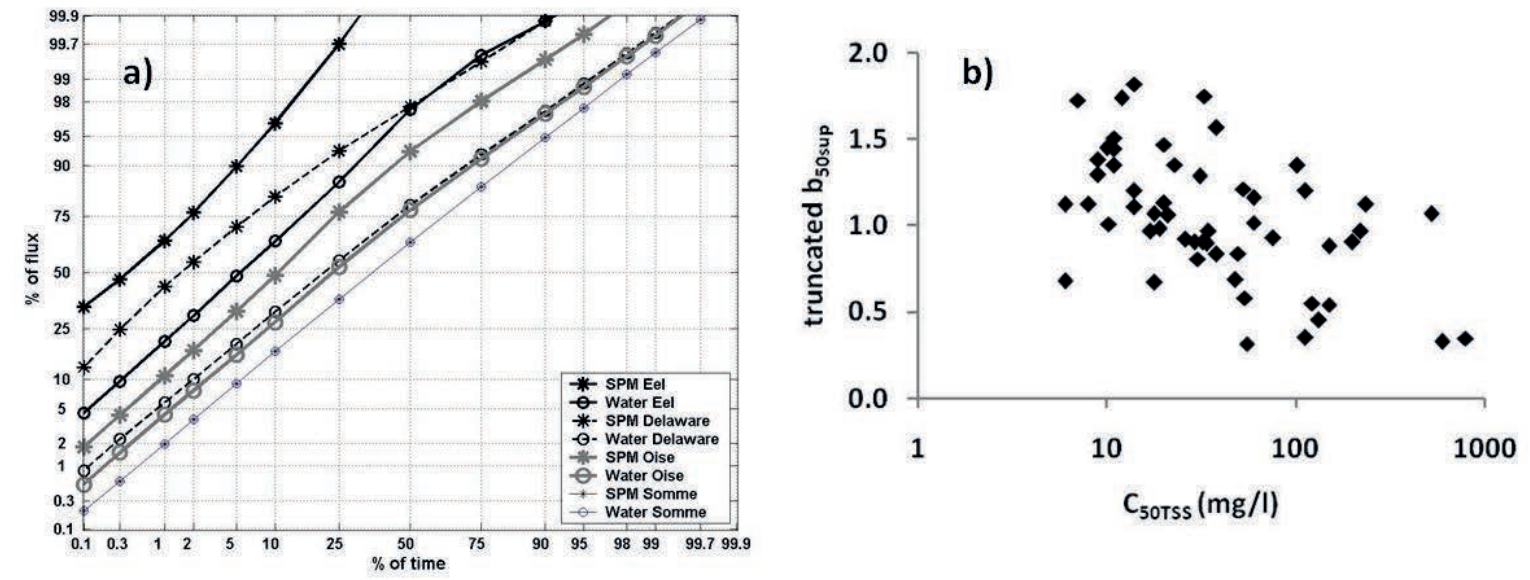

Fig. 3 (a) River flows and sediment fluxes duration curves represented in double probability scales. Mid-latitude basins of similar size: Eel and Delaware (USA) and Oise and Somme (France) rivers (Moatar et al., 2013, Hydrol. Processes, reproduced with permission). (b) Truncated rating curve exponent $\left(\mathrm{b}_{50 \text { sup }}\right) v s$ median TSS in world rivers.

For river basins exceeding $1000 \mathrm{~km}^{2}$, the flow durations in $2 \%$ of time $\left(\mathrm{W}_{2}\right)$ are $3 \%, 10 \%$ and $31 \%$ (minimum, median, maximum) for the global scale database $(\mathrm{n}=57)$ used by Meybeck et al. (2003), and $4.8 \%, 14.4 \%$, and $47 \%$ for the database dominated by US stations $(\mathrm{n}=50)$. The related ranges of sediment flux duration in $2 \%$ of time $\left(\mathrm{M}_{2}\right)$ are much wider in both cases: $10.6 \%, 35 \%$, $92.6 \%$, and $15.9 \%, 42.6 \%, 83.2 \%$ for global rivers and US rivers, respectively. The extreme $\mathrm{M}_{2}$ $(92.6 \%)$ is recorded for the Walla-Walla, located in a dry portion of Washington state (USA) (Table 1). 
The lowest $\mathrm{M}_{2}$ values are observed in the lake-influenced basins, the lacustrine Rhone (10.8\%) (Switzerland) and the St Lawrence (7.9\%), and in the largest basins (6.2\% for the Mississippi).

The duration indicators, $\mathrm{W}_{2}$ and $\mathrm{M}_{2}$, which extend over short ranges, are very sensitive indicators: there is a considerable difference between $\mathrm{M}_{2}=5 \%$ and $\mathrm{M}_{2}=20 \%$. The sediment duration indicator $\mathrm{M}_{2}$ decreases with basin size (Meybeck et al., 2003; Meybeck \& Moatar, 2012), probably due to the increasing deposition of sediment in floodplains as the basin size increases, while the flow duration in $2 \%$ of time is much less affected by basin size (Fig. 2(a)). Other natural control factors of $\mathrm{M}_{2}$ include climate, lake occurrence, basin relief and morphology.

\section{The truncated sediment rating curve ( $b_{50 \text { sup }}$ )}

The last set of indicators is related to the sediment rating curve, i.e. the relationship between $\mathrm{C}$ and q. Like river fluxes, we can focus on the upper half of flow values $\left(q>q_{50}\right)$, which corresponds to the greatest part of riverine fluxes (Meybeck \& Moatar, 2012). To this end, the (C, q) couples are first split into two groups described by two segmented exponents of the rating curve, generally the $\log -\log$ linear correlation $\mathrm{C}=\mathrm{a} \mathrm{q}^{\mathrm{b}}, \mathrm{b}_{50 \mathrm{inf}}$ and $\mathrm{b}_{50 \text { sup }}$ (Fig. 4). The upper half of the rating curve corresponds to the great majority of riverine fluxes for all types of material, even when they are diluted during flows: 61 to $90 \%$ of total fluxes for TDS, 67 to $97.8 \%$ for nitrate and phosphate, and 85 to $99 \%$ for total phosphorus and total Kjeldahl nitrogen. For suspended solids, this proportion ranges between 79 and 99.9\% (median 97.2\%) (Meybeck \& Moatar, 2012). The truncation of the rating curves, i.e. focusing on higher flows, is therefore very suitable for sediment flux studies. The segmentation of the rating curve is particularly justified when $b_{50 \mathrm{inf}}$ and $b_{50 \text { sup }}$ are significantly different. For TSS, both segmented exponents are always positive with differences up to 1 . For other types of fluvial materials, such as nutrients, $b_{50 \text { inf }}$ and $b_{50 \text { sup }}$ can even have opposite signs (Meybeck \& Moatar, 2012). The $b_{50 \text { sup }}$ exponent is another dimensionless indicator which appears to be specific to survey stations and riverine materials: negative for dissolved salts (the dilution process) and positive for riverine particulates and total nutrients (the concentration process). For dissolved nutrients it can be either positive or negative (Meybeck \& Moatar, 2012).

The segmentation of the sediment rating curve is illustrated by the lower Colorado River (440 $000 \mathrm{~km}^{2}$, USA), for the 1931-1941 period prior to the Hoover Dam operation (Fig. 4(a)). Under natural conditions, its flow is moderately variable $\left(\mathrm{q}_{99} / \mathrm{q}_{50}=5.4 ; \mathrm{q}^{*} / \mathrm{q}_{50}=2.0\right)$ and its sediment concentrations are always very high, with TSS concentrations of $4200 \mathrm{mg} \mathrm{L}^{-1}$ for $\mathrm{C}_{50}$ and $55000 \mathrm{mg} \mathrm{L}^{-1}$ for $\mathrm{C}_{99}$, a figure probably close to the world record, reflecting the great erodibility of the basin. The general and extreme variability indicators for TSS and daily yields are very moderate: $\mathrm{C}^{*} / \mathrm{C}_{50}=2.3, \mathrm{C}_{99} / \mathrm{C}_{50}=13.1 ; \mathrm{Y}^{*} / \mathrm{Y}_{50}=4.2, \mathrm{Y}_{99} / \mathrm{Y}_{50}=35$. Duration indicators for the Colorado prior to its damming are also relatively low: $\mathrm{W}_{2}=11$ and $\mathrm{M}_{2}=20$.
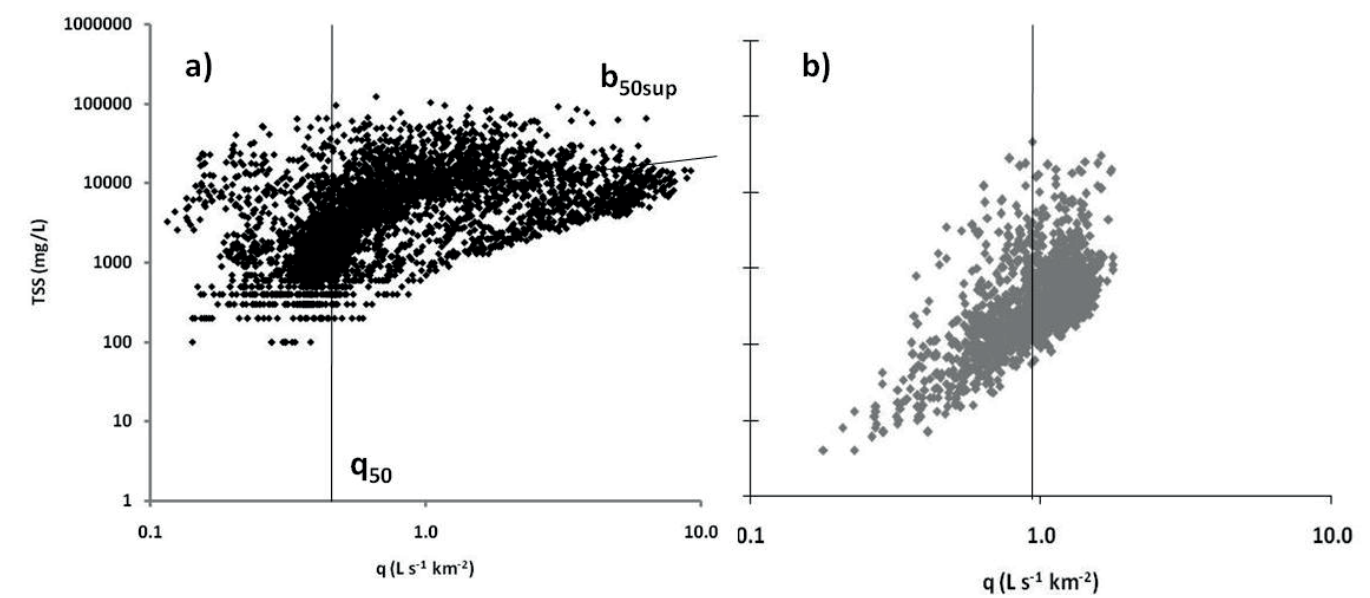

Fig. 4 Truncated rating curve between TSS and river flow in the Colorado River at Grand Canyon (AZ; USGS ID 09402500): (a) prior to the damming impact (1931-1941); (b) afterwards (1964-1971). See Table 1 for related variability metrics. 
Comparison of the Eel and the Colorado shows that high annual sediment yields in rivers may actually correspond to very different modes of sediment transport at the daily scale. Comparison of the $\mathrm{C}$ vs $\mathrm{q}$ relations of several rivers or stations is difficult when the daily measurements are plotted. It can be addressed through the pseudo rating curve, linking the upper percentiles of TSS $\left(\mathrm{C}_{50}, \mathrm{C}_{75}, \mathrm{C}_{90}, \mathrm{C}_{95}, \mathrm{C}_{99}\right)$ with their related percentiles of runoff $\left(\mathrm{q}_{50}, \mathrm{q}_{75}, \mathrm{q}_{90}, \mathrm{q}_{95}, \mathrm{q}_{99}\right)$ (Meybeck et al., 2003). The median TSS $\left(\mathrm{C}_{50}\right)$ is used as a starting point and the pseudo exponent, $\beta_{50-95}$, is similar to the $\mathrm{b}_{50 \text { sup }}$ slope. A comparison of rivers from four different hydroregions illustrates these various pseudo rating curves (Fig. 1(b)). The Walla-Walla (Washington, USA) has an extended range for both $C$ and $q$ and a steep slope $\left(\beta_{50-95}=1.96\right)$. The Peace River (Canada) has the steepest slope in this selection. The St Lawrence has the lowest TSS level and the lowest $\beta_{50-95}$.

It should be noted that truncated and pseudo rating curves only address the first-order control of TSS by river flow. Second-order variations, such as the C-q hysteresis, cannot be described by these approaches.

\section{Distribution and role of truncated $b_{50 \text { sup }}$ exponent for TSS fluxes}

The range of documented $b_{50 \text { sup }}$ is $+0.2,+1.07,+2.0$ (minimum, median, maximum) in the US database. As $b_{50 \text { sup }}$ is an exponent in a log-log relation, this range actually corresponds to a major difference in terms of TSS. With an identical $\left(\mathrm{C}_{50}, \mathrm{q}_{50}\right)$ starting point, a flood runoff equal to ten times the median would generate TSS concentrations 60 times greater for $b_{50 \text { sup }}=2.0$ than for $b_{50 \text { sup }}$ $=0.2$.

The truncated $b_{50 \text { sup }}$ exponent plays a prime role in sediment flux temporality and intensity. TSS variability indicators, $\mathrm{C}^{*} / \mathrm{C}_{50}$ and $\mathrm{C}_{99} / \mathrm{C}_{50}$, depend directly on $\mathrm{b}_{50 \text { sup }}$ (Fig. 5(a) and (b)), which can be considered as the amplifier of TSS variability, either general or extreme, with regard to river runoff. The $b_{50 \text { sup }}$ parameter also accounts for the difference observed for TSS duration indicators and the flow duration indicator $\left(\mathrm{M}_{2}-\mathrm{W}_{2}\right)$. Extreme $\mathrm{b}_{50 \text { sup }}(>1.5)$ corresponds to major and positive $\mathrm{M}_{2}-\mathrm{W}_{2}$ differences, reaching $50 \%$ or more. In other words, in river basins where $10 \%$ of water is carried in $2 \%$ of time, the sediment flux carried in $2 \%$ of time reaches $60 \%$ if $b_{50 \text { sup }}$ is above 1.5 , but is only $20 \%$ if $\mathrm{b}_{50 \text { sup }}$ is 0.4 . For the dilution pattern $\left(\mathrm{b}_{50 \text { sup }}<0\right), \mathrm{W}_{2}$ exceeds $\mathrm{M}_{2}$ for any type of river-borne material (Meybeck \& Moatar, 2012; Moatar et al., 2013).

The influence of $b_{50 \text { sup }}$ on sediment yields is even more pronounced than for concentrations; it links the hydrological variability, as described by the indicators $\mathrm{q}^{*} / \mathrm{q}_{50}, \mathrm{q}_{99} / \mathrm{q}_{50}$, to their related sediment yield variability, $\mathrm{Y}^{*} / \mathrm{Y}_{50}, \mathrm{Y}_{99} / \mathrm{Y}_{50}$ (Fig. 6(a) and (b)). When $\mathrm{b}_{50 \text { sup }}$ increases from 0.4 to 1.4 , these indicators can differ by more than one order of magnitude for the general variability indicators $\left(\mathrm{Y}^{*} / \mathrm{Y}_{50}\right)$ (Fig. 6(a)), and by two orders of magnitude for the extreme variability indicators $\left(\mathrm{Y}_{99} / \mathrm{Y}_{50}\right)$ (Fig. 6(b)).

Considering the major influence of $b_{50 \text { sup }}$ on sediment transport, its role as a controlling factor should be addressed in all the world's rivers. An inverse relationship is observed between $b_{50 \text { sup }}$
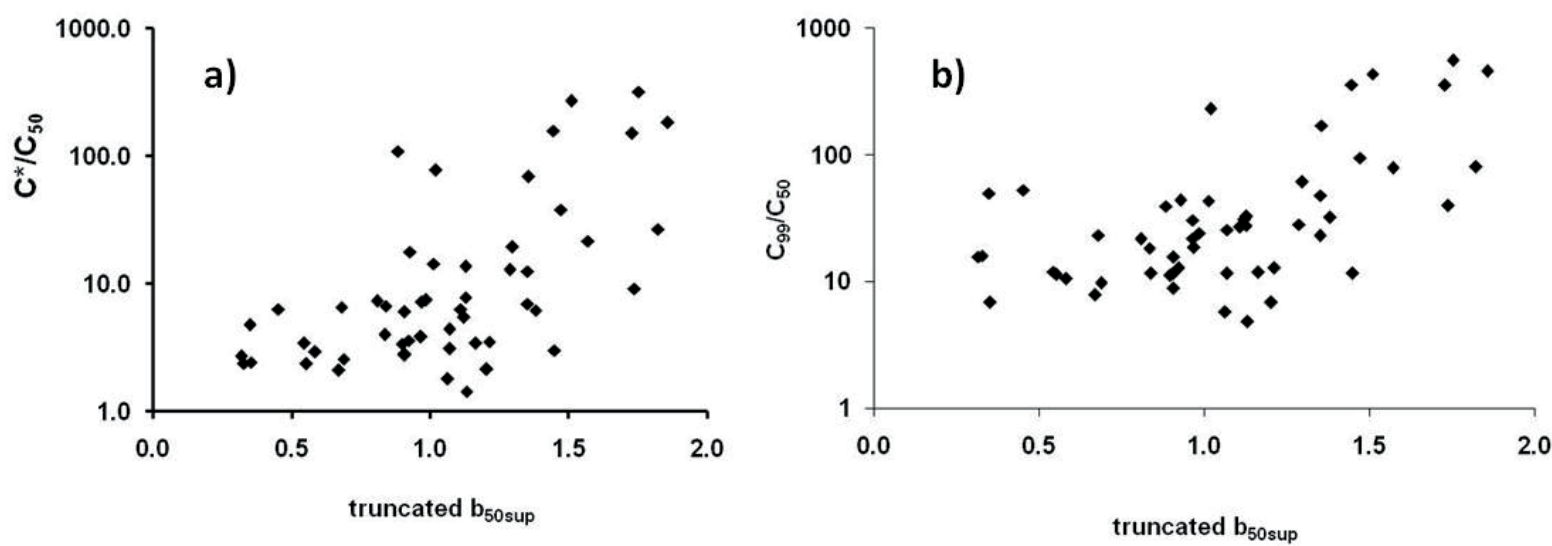

Fig. 5 Control of daily variability concentrations by the truncated $b_{50 \text { sup }}$ exponent: (a) General variability $\mathrm{C}^{*} / \mathrm{C}_{50}$; (b) Extreme variability $\mathrm{C}_{99} / \mathrm{C}_{50}$. 

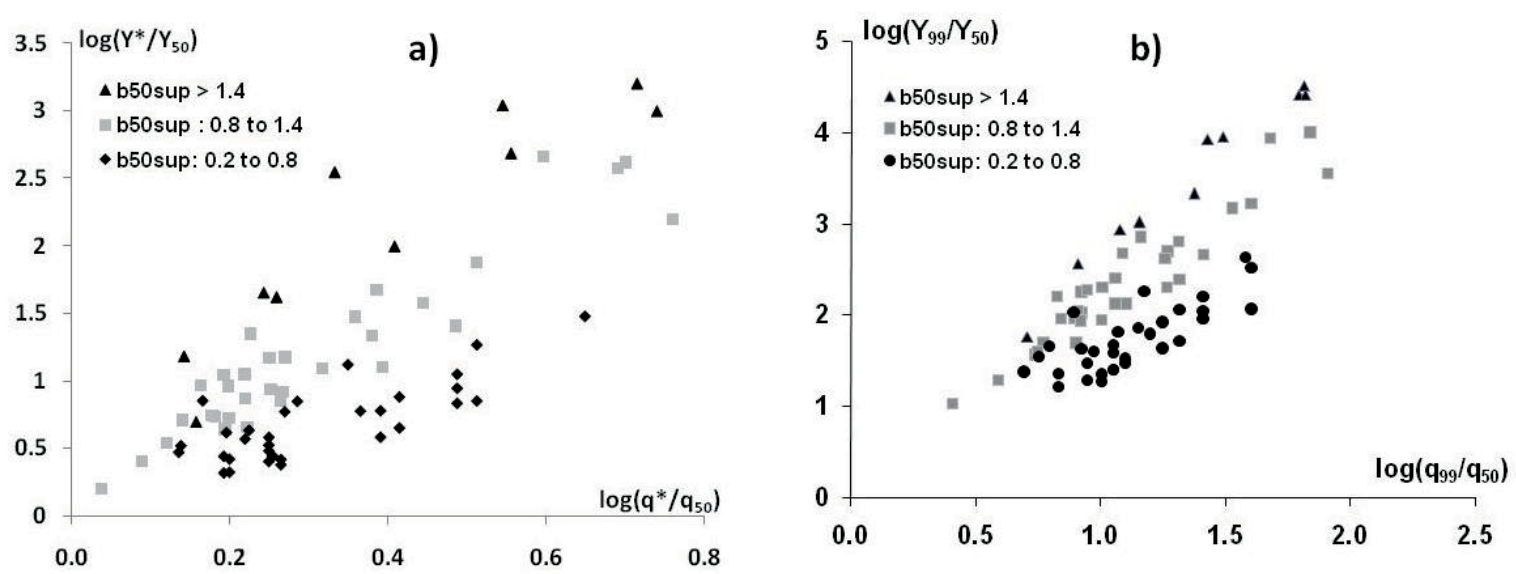

Fig. 6 Daily TSS flux variability $v s$ daily flow variability for three classes of $b_{50 \text { sup: }}$ (a) General flux variability $\left(\mathrm{Y}^{*} / \mathrm{Y}_{50}\right)$ vs general flow variability $\left(\mathrm{q}^{*} / \mathrm{q}_{50}\right)$; (b) Extreme flux variability $\left(\mathrm{Y}_{99} / \mathrm{Y}_{50}\right) v s$ extreme flow variability $\left(\mathrm{q}_{99} / \mathrm{q}_{50}\right)$; log-log scales.

and median TSS concentrations $\left(\mathrm{C}_{50}\right)$ for world rivers (Fig. 3(b)). Very turbid rivers draining highly erodible rocks in dry regions, such as the El Abid (Morocco), the Colorado (1931-41) and the Huang He, have a minimum slope and a very high TSS level, even at low flows. The $\beta_{50-95}$ distribution in the global database is similar to that of $b_{50 \text { sup: }}$ 0.3, 1.2, 4 (minimum, median, maximum, $\mathrm{n}=50$ ). In small river basins (drainage area $<1000 \mathrm{~km}^{2}$ ) $\beta_{50-95}$ may exceed 2.5. It should be noted that in low relief river basins, without mountainous headwaters, $b_{50 \text { sup }}$ is often poorly defined, characterized by dominant $\mathrm{C}$ vs q hysteresis cycles, as in the Ubangi River in central Africa (Coynel et al., 2005) or the Mississippi at some stations (Horowitz et al., 2001).

\section{Influence of river damming on temporal variability indicators}

Damming generates the most dramatic change in the TSS-Q distribution and its daily variability indicators, as illustrated by the Colorado before (1931-1941) and after (1966-1972) the cascade of dams that started with construction of the Hoover Dam in 1935 (Table 1, Fig 4(a) and (b)). After 1941, reservoir sediment trapping started to have an effect on average TSS levels ( $\mathrm{C}^{*}$ ), modifying all indicators of TSS and yields. Runoff distribution was truncated at both ends as a result of sustained low flows and flood control (Fig. 4(b)): the median flow q $\mathrm{q}_{50}$ increased by $50 \%$, from 0.6 to $0.94 \mathrm{~L} \mathrm{~s} \mathrm{~s}^{-1} \mathrm{~km}^{-2}$, and extreme runoff $\mathrm{q}_{99}$ dropped from 6.5 to $1.56 \mathrm{~L} \mathrm{~s}^{-1} \mathrm{~km}^{-2}$ ), while the average flow fell by $25 \%\left(1.2\right.$ to $\left.0.95 \mathrm{~L} \mathrm{~s}^{-1} \mathrm{~km}^{-2}\right)$ as a result of evaporation losses and water withdrawals. The extreme flow variability, once relatively high for such a large basin $\left(\mathrm{q}_{99} / \mathrm{q}_{50}=10.8\right)$ is now very low $\left(\mathrm{q}_{99} / \mathrm{q}_{50}=1.65\right)$. The Colorado, once a permanently turbid river $\left(\mathrm{C}_{50}=4200 \mathrm{mg} \mathrm{L}^{-1}\right)$, is 12 times less turbid since damming $\left(\mathrm{C}_{50}=339 \mathrm{mg} \mathrm{L}^{-1}\right)$. At least $90 \%$ of the suspended sediments are trapped in the reservoirs of Lake Mead and Lake Powell: $\mathrm{C}^{*}$ dropped nearly 10-fold, from 9560 to $1120 \mathrm{mg} \mathrm{L}^{-1}$ and $\mathrm{C}_{99}$ from 55000 to $16000 \mathrm{mg} \mathrm{L}^{-1}$. The remaining fluxes could be due to channel erosion downstream of the dam. The general daily TSS variability, relatively low prior to damming, increased slightly: $\mathrm{C}^{*} / \mathrm{C}_{50}$ rose from 2.26 to 3.3 , an unexpected finding. By contrast, the fall in extreme variability was expected: $\mathrm{C}_{99} / \mathrm{C}_{50}$ fell from 130 to 1.39 . The truncated $\mathrm{b}_{50 \text { sup }}$ exponent, once very low and typical of a permanently turbid river, has increased considerably, from 0.17 to 1.7 . The flow duration $\left(\mathrm{W}_{2}\right)$ decreased from 11 to $3.4 \%$, and the sediment flux duration $\left(\mathrm{M}_{2}\right)$ from 20 to $10 \%$.

This analysis of the impact of damming should be generalized to world river basins where both river flow and sediment transport are highly regulated by dams (Vörösmarty et al., 2003, Syvitski et al., 2005), in order to generate a typology of reservoir impacts on TSS transport: natural controls are now completely masked by the flow regulation of dams and by the storage of sediment in reservoirs. TSS temporality is totally under human control. 


\section{CONTROL OF RIVER PARTICULATE CHEMISTRY BY TSS CONTENTS AND SEDIMENT YIELDS}

Three effects of TSS and sediment yields on river particulate matter (RPM) chemistry are considered here: (i) the control of major elements ( $\mathrm{Si}, \mathrm{Al}, \mathrm{Fe}, \mathrm{Ti}, \mathrm{Mn}, \mathrm{Ca}, \mathrm{Mg}, \mathrm{Na}$ and $\mathrm{K}$ ), (ii) the control of particulate organic carbon (POC), and (iii) the control of river particulate contaminants such as heavy metals (cadmium).

\section{Control of RPM chemical weathering by TSS and sediment yields}

Our database of world RPM chemistry (Table 2), initiated a long time ago (Martin \& Meybeck, 1979), has been updated (see Meybeck, 2013, 2014), with regional studies, such as Gaillardet et al. (1997, 1999, 2003) in British Columbia, Central Africa and Amazonia, Guyot (1992) in Bolivia, Gaiero et al. (2002) in Patagonia, Rachold (1999) in Siberia, Canfield (1997) in the USA, MoreiraTurq et al. (2003) in the Amazon, in Central Asia (Gordaev and Lisitzin, 1978) and with global scale surveys (Gordeev \& Lisitzin, 1978; Savenko, 2007; Viers et al., 2008). Figures for river sediment fluxes and runoff for these major rivers are taken from pre-damming surveys (Meybeck \& Ragu, 1996; Milliman \& Farnworth, 2011).

Major elements are always expressed in relative proportions (their sum expressed as oxide is close to $100 \%$ ), i.e. when $\mathrm{SiO}_{2}$ (as quartz) increases, all other major elements decrease. Therefore, it is preferable to consider elemental ratios when assessing correlations (e.g. $\mathrm{Fe} / \mathrm{Ti}, \mathrm{Na} / \mathrm{K}, \mathrm{Mg} / \mathrm{Al}$, etc.). The most salient ratio for major elements (Meybeck, 2014) is Chemical Weathering Intensity (CWI), a ratio defined as $(\mathrm{Al}+\mathrm{Fe}+\mathrm{Ti}) /(\mathrm{Mg}+\mathrm{Na}+\mathrm{K})$. $\mathrm{CWI}$ is a dimensionless indicator of the state of chemical weathering of the transported RPM; it is independent of the carbonate and/or quartz contents. Some missing data in the CWI formula, for example, Ti, have been estimated on the basis of similarities between basins (less than $1 \%$ of data).

Our global-scale chemistry database for river basins originates from all continents and relief types (Table 2A). It covers $47.5 \times 10^{6} \mathrm{~km}^{2}$ (average runoff $369 \mathrm{~mm} /$ year, average sediment yield $137 \mathrm{t} \mathrm{year}^{-1} \mathrm{~km}^{-2}$. It is therefore assumed to be representative of world rivers (Milliman \& Farnworth, 2011). The database also includes all hydrobelts, in which average temperatures range from -9.7 to $26.3^{\circ} \mathrm{C}$, and average runoff ranges from 6 to $1393 \mathrm{~mm}$ year ${ }^{-1}$ (Meybeck et al., 2013).

The CWI ranges from less than 2 (1.6 for the Northern Dvina), where RPM is not weathered, to more than 20 for the most weathered material, carried by the Congo and Ubangi rivers. The control of CWI by TSS and $\mathrm{Y}^{*}$ is studied here with regard to the major hydroclimatic belts, delineated by the boundaries of major river basins as defined by Meybeck et al. (2013). The database illustrates the limited controlling effect of temperature on TSS levels and yields, here differentiated by hydrobelts, i.e. by temperature then runoff: both $\mathrm{C}^{*}$ and $\mathrm{Y}^{*}$ extend over three orders of magnitude in each belt; as previously mentioned, they are controlled by multiple other factors (Fig. 7(a) and (b)).

In the cold boreal (BOR, Siberian rivers, the Mackenzie River, rivers in Alaska and British Columbia) and arid basins of Central Asia (DRY, the Amu Darya and Syr Darya rivers), CWI is not affected by TSS concentration. CWI is also very constant in the mid-latitude basins (MLT), i.e. the temperate regions found in all continents (e.g. the Mississippi, St Lawrence, Indus, Ganges, Brahmaputra, Chang Jiang, Huang He, rivers in western Europe, Patagonia and the Caucasus), with a few exceptions for the Rhine, the Min and the Murray-Darling, where the CWI levels are somewhat higher. In contrast to the above-mentioned hydrobelts, the hot subtropical and equatorial basins (TRP), here represented by Amazonian, Sahelian and central African rivers and by some Asian rivers, the Mekong and Zhu Jiang, CWI is clearly linked to TSS: highest values (CWI $>20)$ are found in the Congo and Ubangi, and lowest values $(\mathrm{CWI}<3)$ are observed in tropical highlands, for example, the Upper Madeira tributaries in Amazonia (data from Guyot, 1992).

The controlling effect of sediment yield (Fig. 7(b)) on CWI is similar, in the following order: $\mathrm{CWI}_{\mathrm{TRP}}>>\mathrm{CWI}_{\mathrm{MLT}}>=\mathrm{CWI}_{\mathrm{BOR}}=\mathrm{CWI}_{\mathrm{DRY}}$. In mountainous river basins, where sediment yields exceed $200 \mathrm{t} \mathrm{year}^{-1} \mathrm{~km}^{-2}$ (the Ganges, Indus and Brahmaputra in the Himalayas, the Amu-Darya 
Table 2 Chemical weathering index (CWI) of river particulate matter (RPM) in relation to sediment transport: A - World medium and large rivers, B - Fine and coarse RPM in a set of rivers, C - World averages compared to average shales, greywackes, and sandstones: WWA $=$ world sediment weighted averages, $\mathrm{WA}=$ world average, $\mathrm{C}_{50}=$ medians, (1) Meybeck, 2013; (2) Viers et al., 2009; (3) Reimann \& de Caritat, 1998; (4) This work. Y* sediment yield; $\mathrm{C}^{*}$ weighted suspended sediment concentrations. BOR, MLT, TRP, DRY: boreal, mid-latitude, tropical and dry hydrobelts (Meybeck et al, 2013). HR, MR, LR: high, medium and low relief.

\begin{tabular}{|c|c|c|c|c|c|c|c|c|c|c|c|}
\hline & $\begin{array}{c}\text { clim ate } \\
-\end{array}$ & $\begin{array}{c}\text { relief } \\
-\end{array}$ & $\begin{array}{c}\text { Area } \\
10^{3} \mathrm{~km}^{2}\end{array}$ & $\frac{q}{m m y^{-1}}$ & $\begin{array}{c}\mathrm{C}^{*} \\
\mathrm{mg} \mathrm{L}^{-1}\end{array}$ & $\begin{array}{c}Y^{*} \\
t k^{-2} y^{-1}\end{array}$ & $\begin{array}{c}\text { Al } \\
\text { ppm }\end{array}$ & $\begin{array}{c}\text { CWI } \\
-\end{array}$ & $\begin{array}{c}\text { KIAI } \\
-\end{array}$ & $\begin{array}{c}\mathrm{Na} / \mathrm{Al} \\
-\end{array}$ & $\begin{array}{c}\mathrm{Si} / \mathrm{Al} \\
-\end{array}$ \\
\hline \multicolumn{12}{|c|}{ A CWI in world rivers } \\
\hline Amur & BOR & LR & 1900 & 184 & 149 & 27 & 62700 & 3.3 & 0.17 & 0.15 & \\
\hline Khatanga & BOR & LR & 360 & 278 & 17 & 5 & 68800 & 3.0 & 0.15 & 0.15 & \\
\hline Lena & BOR & LR & 2500 & 208 & 38 & 8 & 71000 & 2.3 & 0.30 & 0.19 & \\
\hline Mackenzie & BOR & MR & 1800 & 172 & 323 & 56 & 70200 & 2.6 & 0.27 & 0.05 & 3.4 \\
\hline Matanuska & BOR & $H R$ & 5.3 & 1887 & 600 & 1132 & 72000 & 2.7 & 0.13 & 0.22 & \\
\hline Mezen & BOR & LR & 78 & 346 & 33 & 12 & 73900 & 2.0 & 0.54 & 0.14 & 2.9 \\
\hline N. Dvina & BOR & LR & 360 & 306 & 41 & 13 & 63850 & 1.6 & 0.64 & 0.16 & 3.8 \\
\hline Nass & BOR & HR & 20.7 & 1357 & & & 73400 & 2.7 & 0.20 & 0.20 & 4.1 \\
\hline $\mathrm{Ob}$ & BOR & LR & 3000 & 130 & 41 & 5.3 & 67880 & 2.2 & 0.41 & 0.23 & 3.7 \\
\hline Pechora & BOR & LR & 320 & 406 & 34 & 14 & 76350 & 2.3 & 0.33 & 0.24 & 3.4 \\
\hline Skeena & BOR & $H R$ & 55 & 1009 & 198 & 200 & 83650 & 3.1 & 0.16 & 0.23 & 3.4 \\
\hline Stikine & BOR & $\mathrm{HR}$ & 53 & 953 & 396 & 377 & 75070 & 2.7 & 0.21 & 0.20 & 3.9 \\
\hline Yana & BOR & LR & 240 & 133 & 94 & 13 & 68700 & 2.4 & 0.32 & 0.23 & \\
\hline Yennissei & BOR & LR & 2590 & 239 & 10 & 2.3 & 84974 & 3.2 & 0.20 & 0.17 & 3.3 \\
\hline Murray- Darling & MLT & LR & 1100 & 22 & 42 & 0.9 & 106000 & 8.7 & 0.01 & 0.07 & 2.9 \\
\hline Parana & MLT & MR & 2600 & 204 & 170 & 35 & 90000 & 3.6 & 0.26 & 0.09 & 3.0 \\
\hline Brahmaputra & MLT & $\mathrm{HR}$ & 670 & 940 & 857 & 806 & 56000 & 2.7 & 0.22 & 0.06 & 5.1 \\
\hline Chang Jiang & MLT & MR & 1800 & 500 & 522 & 261 & 81800 & 3.0 & 0.25 & 0.09 & 3.6 \\
\hline Don & MLT & LR & 422 & 67 & 77 & 5.1 & 96760 & 3.7 & 0.24 & 0.05 & 2.9 \\
\hline Ganges & MLT & $\mathrm{HR}$ & 980 & 500 & 1061 & 531 & 77000 & 2.7 & 0.27 & 0.14 & 3.7 \\
\hline Gironde & MLT & MR & 80 & 438 & 86 & 38 & 79000 & 3.3 & 0.27 & 0.06 & 2.7 \\
\hline Huai & MLT & MR & 260 & 85 & 636 & 54 & 54800 & 2.4 & 0.40 & 0.18 & \\
\hline Huang He & MLT & MR & 750 & 57 & 23256 & 1333 & 72500 & 2.4 & 0.25 & 0.15 & 4.2 \\
\hline Indus & MLT & $H R$ & 916 & 98 & 2778 & 273 & 91389 & 2.3 & 0.34 & 0.09 & 3.1 \\
\hline Kizil Irmak & MLT & MR & 76 & 76 & 4000 & 304 & 59000 & 2.0 & 0.24 & 0.16 & \\
\hline Luang He & MLT & MR & 54 & 426 & 1000 & 426 & 59500 & 2.0 & 0.41 & 0.17 & \\
\hline Min & MLT & MR & 61 & 951 & 133 & 126 & 97700 & 5.8 & 0.17 & 0.05 & \\
\hline Qian Tang & MLT & MR & 42 & 738 & 142 & 105 & 74800 & 3.1 & 0.26 & 0.07 & \\
\hline Rhine & MLT & MR & 224 & 310 & 49 & 15 & 68381 & 5.5 & 0.11 & 0.01 & 3.5 \\
\hline Rhone & MLT & $\mathrm{HR}$ & 96 & 563 & 115 & 65 & 61900 & 3.0 & 0.29 & 0.06 & \\
\hline Rio Grande (USA) & MLT & LR & 870 & 21 & 1111 & 23 & 62000 & 2.3 & 0.29 & 0.16 & \\
\hline Saint Law rence & MLT & LR & 1200 & 283 & 14 & 3.8 & 67000 & 2.9 & 0.29 & 0.21 & 3.3 \\
\hline Seine & MLT & LR & 65 & 200 & 54 & 11 & 61300 & 4.9 & 0.20 & 0.03 & 3.2 \\
\hline Shatt el Arab & MLT & MR & 420 & 183 & 1299 & 238 & 49000 & 2.2 & 0.15 & 0.24 & 5.3 \\
\hline Ural & MLT & LR & 82 & 42 & 496 & 21 & 76555 & 3.0 & 0.25 & 0.08 & 3.2 \\
\hline Volga & MLT & LR & 1350 & 181 & 102 & 19 & 91800 & 3.4 & 0.24 & 0.07 & 3.2 \\
\hline Amu Darya & DRY & MR & 450 & 110 & 1903 & 209 & 75446 & 2.3 & 0.22 & 0.18 & 3.2 \\
\hline Chari & DRY & LR & 600 & 200 & 23 & 4.7 & 151000 & 18.0 & 0.05 & 0.01 & 1.4 \\
\hline$\| i$ & DRY & MR & 114 & 129 & 619 & 80 & 74678 & 2.4 & 0.29 & 0.17 & 3.3 \\
\hline Narym & DRY & MR & 64 & 281 & & & 54772 & 1.9 & 0.31 & 0.18 & 3.9 \\
\hline Syr Darya & DRY & MR & 219 & 98 & 563 & 55 & 71508 & 2.0 & 0.23 & 0.21 & 3.2 \\
\hline Amazon & TRP & MR & 6300 & 1000 & 190 & 190 & 124000 & 4.6 & 0.21 & 0.06 & 2.2 \\
\hline Amazon & TRP & MR & 6300 & 1000 & 190 & 190 & 124000 & 4.6 & 0.21 & 0.06 & 2.2 \\
\hline Congo & TRP & LR & 3800 & 342 & 33 & 11 & 158700 & 14.1 & 0.06 & 0.01 & 1.5 \\
\hline Niger & TRP & LR & 200 & 950 & 211 & 200 & 112800 & 6.9 & 0.14 & 0.03 & 2.0 \\
\hline Orange & TRP & MR & 1000 & 11 & 7835 & 89 & 91217 & 2.1 & 0.28 & 0.30 & 3.3 \\
\hline Orinoco & TRP & MR & 1100 & 1000 & 191 & 191 & 113000 & 4.5 & 0.24 & 0.07 & 2.6 \\
\hline Rio Negro & TRP & LR & 750 & 1904 & 5.3 & 10 & 180529 & 15.3 & 0.05 & 0.02 & 1.3 \\
\hline Senegal & TRP & LR & 441 & 55 & 78 & 4.3 & 112000 & 8.1 & 0.13 & 0.02 & 2.7 \\
\hline Song Cai (Hong He) & TRP & $H R$ & 160 & 750 & 917 & 688 & 98700 & 3.8 & 0.26 & 0.04 & 2.6 \\
\hline Zhu Jiang & TRP & MR & 490 & 531 & 308 & 163 & 111100 & 5.6 & 0.17 & 0.03 & 2.2 \\
\hline
\end{tabular}

Table $2 \mathrm{~B}$ and $2 \mathrm{C}$ continue on the next page. 
Table 2, continued.

\begin{tabular}{|c|c|c|c|c|c|c|c|c|c|c|c|}
\hline & $\begin{array}{c}\text { climate } \\
-\end{array}$ & $\begin{array}{c}\text { relief } \\
-\end{array}$ & $\begin{array}{c}\text { Area } \\
10^{3} \mathrm{~km}^{2}\end{array}$ & $\begin{array}{c}q \\
m y^{-1}\end{array}$ & $\begin{array}{c}\mathrm{C}^{*} \\
\mathrm{mg} \mathrm{L}^{-1}\end{array}$ & $\begin{array}{c}Y^{*} \\
t k^{-2} y^{-1}\end{array}$ & $\begin{array}{c}\text { Al } \\
\text { ppm }\end{array}$ & $\begin{array}{c}\text { CWI } \\
-\end{array}$ & $\begin{array}{c}\mathrm{KIAI} \\
-\end{array}$ & $\begin{array}{c}\mathrm{Na} / \mathrm{Al} \\
-\end{array}$ & $\begin{array}{c}\text { Si/AI } \\
-\end{array}$ \\
\hline \multicolumn{12}{|c|}{$B$ CWI in fine and coarse particulate material } \\
\hline Mackenzie SPM & BOR & $\mathrm{MR}$ & & & & & 74200 & & & & 4.0 \\
\hline Mackenzie Sand & BOR & MR & & & & & 46700 & 2.3 & 0.10 & 0.10 & 7.4 \\
\hline Stikine SPM & BOR & HR & & & & & 75070 & 2.7 & 0.21 & 0.20 & 3.9 \\
\hline Stikine sand & BOR & HR & & & & & 59500 & 2.2 & 0.25 & 0.29 & 5.7 \\
\hline Senegal SPM & TRP & LR & & & & & 112000 & 8.1 & 0.13 & 0.02 & 2.7 \\
\hline Senegal sand & TRP & LR & & & & & 64000 & 4.6 & 0.24 & 0.05 & 5.7 \\
\hline Danube SPM & MLT & MR & & & & & 62800 & & 0.25 & 0.19 & 4.7 \\
\hline Danube sand & MLT & MR & & & & & 45900 & & 0.27 & 0.22 & 6.4 \\
\hline Kali SPM & TRP & LR & & & & & 135800 & & 0.13 & 0.04 & \\
\hline Kali sand & TRP & LR & & & & & 88700 & & 0.15 & 0.16 & \\
\hline Mekong SPM & MLT & HR & & & & & 77000 & 3.3 & 0.27 & 0.09 & \\
\hline Mekong sand & MLT & $H R$ & & & & & 30000 & 1.9 & 0.50 & 0.16 & \\
\hline Coruh SPM & MLT & HR & & & & & 65000 & 3.1 & 0.17 & 0.12 & \\
\hline Coruh sand & MLT & $\mathrm{HR}$ & & & & & 78000 & 2.8 & 0.17 & 0.22 & \\
\hline \multicolumn{12}{|c|}{ C World averages } \\
\hline Sandstone(3) & & & & & & & 37000 & 1.4 & 0.30 & 0.46 & 10.9 \\
\hline Greyw acke (3) & & & & & & & 71450 & 2.2 & 0.23 & 0.31 & 4.5 \\
\hline Shale (3) & & & & & & & 91000 & 2.7 & 0.30 & 0.14 & 3.2 \\
\hline WWA (1) & & & & & & & 83000 & 3.4 & 0.22 & 0.11 & 3.3 \\
\hline WA (2) & & & & & & & 87200 & 4.1 & 0.19 & 0.08 & 2.9 \\
\hline $\mathrm{C}_{50} \mathrm{BOR}(4)$ & BOR & & & & & & 69400 & 2.9 & 0.23 & 0.13 & 4.1 \\
\hline $\mathrm{C}_{50} \mathrm{MLT}(4)$ & MLT & & & & & & 68000 & 3.0 & 0.25 & 0.12 & 4.2 \\
\hline $\mathrm{C}_{50} \operatorname{TRP}(4)$ & TRP & & & & & & 92640 & 5.7 & 0.16 & 0.04 & 2.8 \\
\hline
\end{tabular}

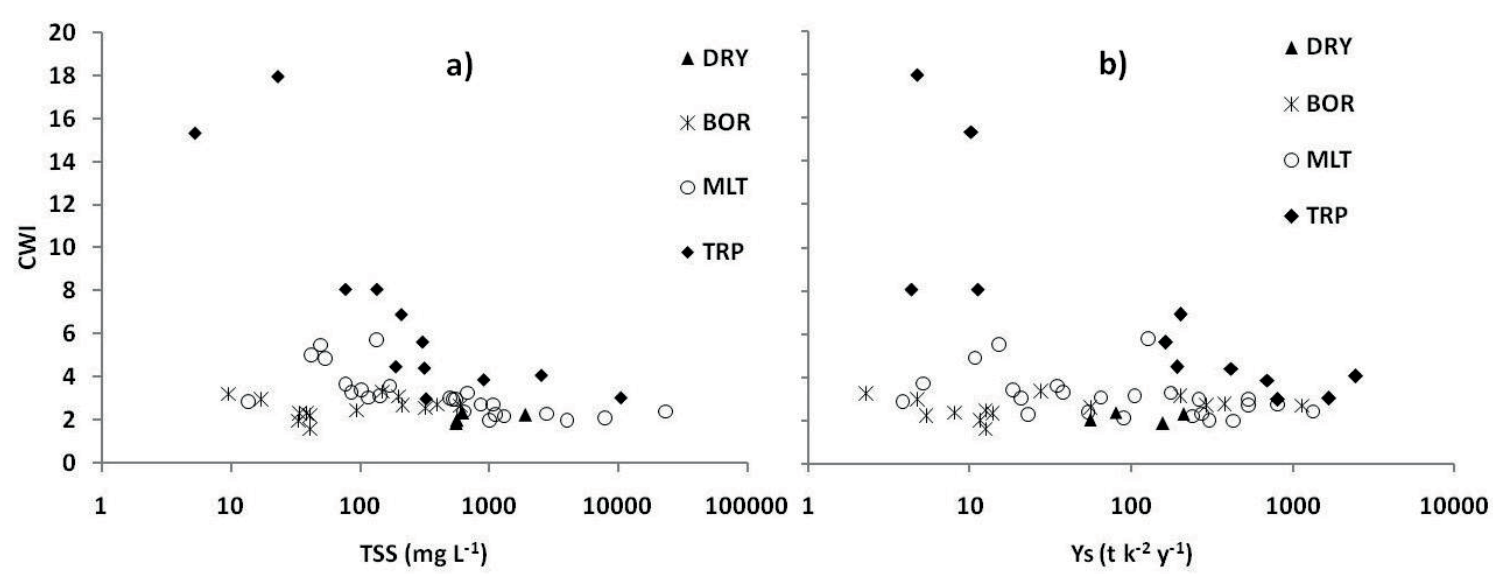

Fig. 7 Linking the Chemical Weathering Index of river particulate matter to river sediment flux indicators: (a) with flow-weighted average TSS contents $\left(\mathrm{C}^{*}, \mathrm{mg} \mathrm{L}^{-1}\right)$; (b) with average sediment yields $\left(\mathrm{Y}^{*}, \mathrm{t}\right.$ year-1 $\left.\mathrm{km}^{-2}\right) . \mathrm{BOR}=$ boreal, MLT $=$ Mid Latitude, DRY $=$ dry, TRP $=$ subtropical and equatorial basins.

and Syr Darya in Central Asia, the Kuban and Rioni in the Caucasus, the Colorado in the southern Rockies, the Matanuska, Nass and Stikine in the northern Rockies, the Po and Rhone in the Alps), the particulate matter carried by rivers is the least weathered, with CWI ranging from 2 to 3 , a ratio very similar to those found for parent crystalline rocks (CWI from 1.5 to 2.4) or for detrital sedimentary rocks (CWI from 2.2 to 2.7) (Table 2C). In boreal rivers, the low CWI is attributed to the occurrence of two sediment sources: fluvio-glacial deposits and thin soil layers, both very recent and mostly unweathered.

For tropical lowlands (the lower Amazon, the Orinoco, the Congo, and sub-Sahelian rivers) RPM is almost totally depleted in $\mathrm{Na}, \mathrm{K}$ and $\mathrm{Mg}$ but enriched in $\mathrm{Al}, \mathrm{Fe}$ and $\mathrm{Ti}$, while the current chemical weathering is very low: minimum total dissolved salt export is recorded in these tropical lowlands (Meybeck, 2003). In these basins, high CWI does not reflect the current chemical erosion rate but results from cumulated weathering over millions of years in tectonically stable regions. By 
contrast, in tropical highlands, such as the Bolivian Andes, where the average temperature is 10 to $20^{\circ} \mathrm{C}$ higher than most other world mountains, CWI is intermediate, between tropical lowlands and other mountain rivers: it ranges from 3 to 4.4 , suggesting that chemical weathering plays a secondary role, limited by the high mechanical erosion.

The calculated CWI for average shales (2.7) and greywackes (2.2) (Table 2C) is close to the present RPM figures for cold and temperate mountain regions, suggesting that these types of environment were the main sources of these materials in past geological periods, and that lowland tropical climates had a limited contribution to the past formation of shale. Previous estimates of average river composition were based on arithmetical averages of major river analyses and were biased by tropical rivers, mainly the Amazon (Martin \& Meybeck, 1979; Gordeev \& Lisitzin, 1978; Viers et al., 2008). As a result, the average river CWI (3.7 to 4.1), calculated on these previous figures are higher than CWI for shales (2.7). The average RPM composition, here weighted by river sediment fluxes (Meybeck, 2014), provides figure closer to the shale average $(\mathrm{CWI}=3.36)$.

The influence of grain size on RPM chemistry is important. River sand composition is more enriched in silica and depleted in all other elements (Al, Fe, Mg) than shales (Potter, 1978). The compositions of coarse and fine fractions, sampled at the same stations in a set of eight rivers, confirms these differences and the similarity of the coarse fraction with sandstone - the detrital sedimentary rock originating from river sand deposits (Table $2 \mathrm{~B}$ ). The $\mathrm{Si} / \mathrm{Al}$ ratio is the most salient ratio controlled by grain size, with higher values for fine RPM and shales compared to coarse $\mathrm{RPM}$ and sandstone [( $\mathrm{Si} / \mathrm{Al})$ sandstone/( $\mathrm{Si} / \mathrm{Al})$ shale $=10.9 / 3.2]$. Furthermore, $\mathrm{Na} / \mathrm{Al}$ is higher in coarse than fine RPM, as in their related sedimentary rocks $[(\mathrm{Na} / \mathrm{Al})$ sandstone $/(\mathrm{Na} / \mathrm{Al})$ shale $=0.46 / 0.14]$, an indication of less weathered mineral debris occurrence in the coarse fraction. Other chemical ratios, such as $\mathrm{Ti} / \mathrm{Al}, \mathrm{Fe} / \mathrm{Al}, \mathrm{Mg} / \mathrm{Al}$, do not show significant differences between coarse and fine fractions in our dataset. The behavior of calcite with grain size is variable: calcite can be preferentially transported in either the fine fraction (e.g. the Coruh River, Turkey/Georgia) or coarse fraction (the Upper Danube and the Mackenzie).

\section{Control of river POC content by TSS and sediment yields}

Since the pioneering studies by Malcolm and Durum (1976) for US rivers, and by Degens et al. (1991) for world rivers, the river POC has been studied in all hydrobelts (Kao \& Liu, 1997; Moreira-Turcq et al., 2003; Coynel et al., 2005). Details of POC and pre-damming TSS databases for large rivers can be found in Meybeck (2005) and Coynel et al. (2005). The key feature of river POC content, expressed as a percentage of TSS, is the inverse POC $\%$ vs TSS relationship, which is widely observed (i) for individual samples collected from a given sampling station, and (ii) for the sediment-weighted average POC and TSS contents at stations (Meybeck, 1982; Coynel et al., 2005). Surficial sources of organic matter, such as soil material, vegetation debris from riparian and floodplain forest, and macrophyte detritus, dominating at low flows and in lowland basins, are diluted during floods by more inorganic RPM originating from soil erosion. For given river stations, POC content ( $\%$ of TSS) may range over one order of magnitude, while TSS range over 2 to 3 orders of magnitude (Fig 8(a)). At low flows and low TSS, POC may reach 10\%. For extreme TSS, exceeding $1000 \mathrm{mg} \mathrm{L}^{-1}$, POC levels are generally below $2 \%$.

For annual POC and TSS averages, a similar pattern is observed (Fig. 8(b)), with maximum POC exceeding 10\% for lowland basins, as in the Rio Negro (Moreira-Turq et al., 2003) and the Congo (Coynel et al., 2005), and at lake outlets (St Lawrence). Minimum POC contents are found in basins with maximum mechanical erosion, such as the Huang He, the tributaries of the Amazon in the Andes, and in Taiwan rivers (Kao \& Liu, 1997). In extremely turbid rivers, the POC content can be below $1 \%$, and the contribution of fossil POC from sedimentary rocks may be dominant, as observed in the Huang He River which erodes the Loess Plateau. In Taiwanese rivers during tropical storms, fossil POC originating from shale erosion represents up to $70 \%$ of total POC (Kao \& Liu, 1997). 

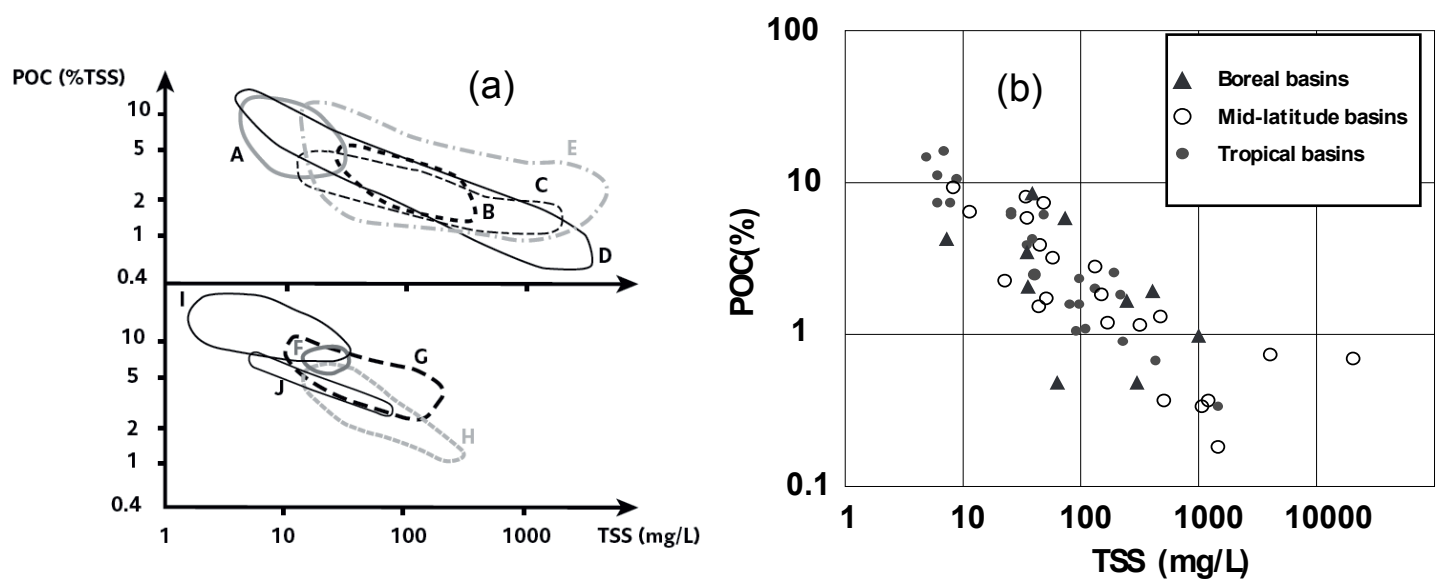

Fig. 8 Relationship between POC and TSS. (a) Individual measurements of POC (\% of TSS) and Total Suspended Solids $\left(\mathrm{mg} \mathrm{L}^{-1}\right)$ in major world rivers (data from Malcolm \& Durum, 1976, and Degens et al., 1991). Envelopes of general distributions. Mid-Latitude basins: $\mathrm{A}=$ St Lawrence, $\mathrm{B}=$ Mississippi, $\mathrm{C}=$ Indus, $\mathrm{D}=$ Missouri, $\mathrm{E}=$ Yang Tse; Tropical basins: $\mathrm{F}=$ Niger, $\mathrm{G}=$ Congo, $\mathrm{H}=$ Orinoco, $\mathrm{I}=$ Ubangi, $\mathrm{J}=$ Mpoko (Ubangi tributary). (b) Average particulate carbon content, as \% of TSS, vs average TSS (mg L ${ }^{-1}$ ) in major world rivers. Boreal basins, mid-latitude basins, subtropical and tropical basin (Redrawn from Meybeck, 2006 and Coynel et al., 2005).

\section{Caution when computing POC fluxes: the example of the Rhone}

The POC-TSS relationship should be taken into account when computing POC fluxes at stations. In the Rhone (France), the 10-year river flow record (Q) from 1994 to 2004 has been segmented into 15 equal flow intervals (POC and TSS data from Sempere et al., 2000). For each interval, the TSS fluxes have been computed, based on the TSS vs Q relationship, including an extreme flood event in 1994 during which TSS exceeded $5000 \mathrm{mg} \mathrm{L}^{-1}$. The general POC vs TSS relationship was then applied to reconstruct POC fluxes for each interval. The minimum POC content during the flood event was $0.5 \%$, i.e. a value similar to the POC in the Durance tributary shales, suggesting that fossil POC was dominant during this event. The extreme flood events $\left(\mathrm{q}>70 \mathrm{~L} \mathrm{~s}^{-1} \mathrm{~km}^{-2}\right)$ represented $0.5 \%$ of time, $2.2 \%$ of river flow, $21.4 \%$ of TSS fluxes, and $10.2 \%$ of soil POC fluxes (Fig. 9). The low-flow period ( $\mathrm{q}<10 \mathrm{~L} \mathrm{~s}^{-1} \mathrm{~km}^{-2}$ ) represented $34.3 \%$ of time, but only $17.3 \%$ of
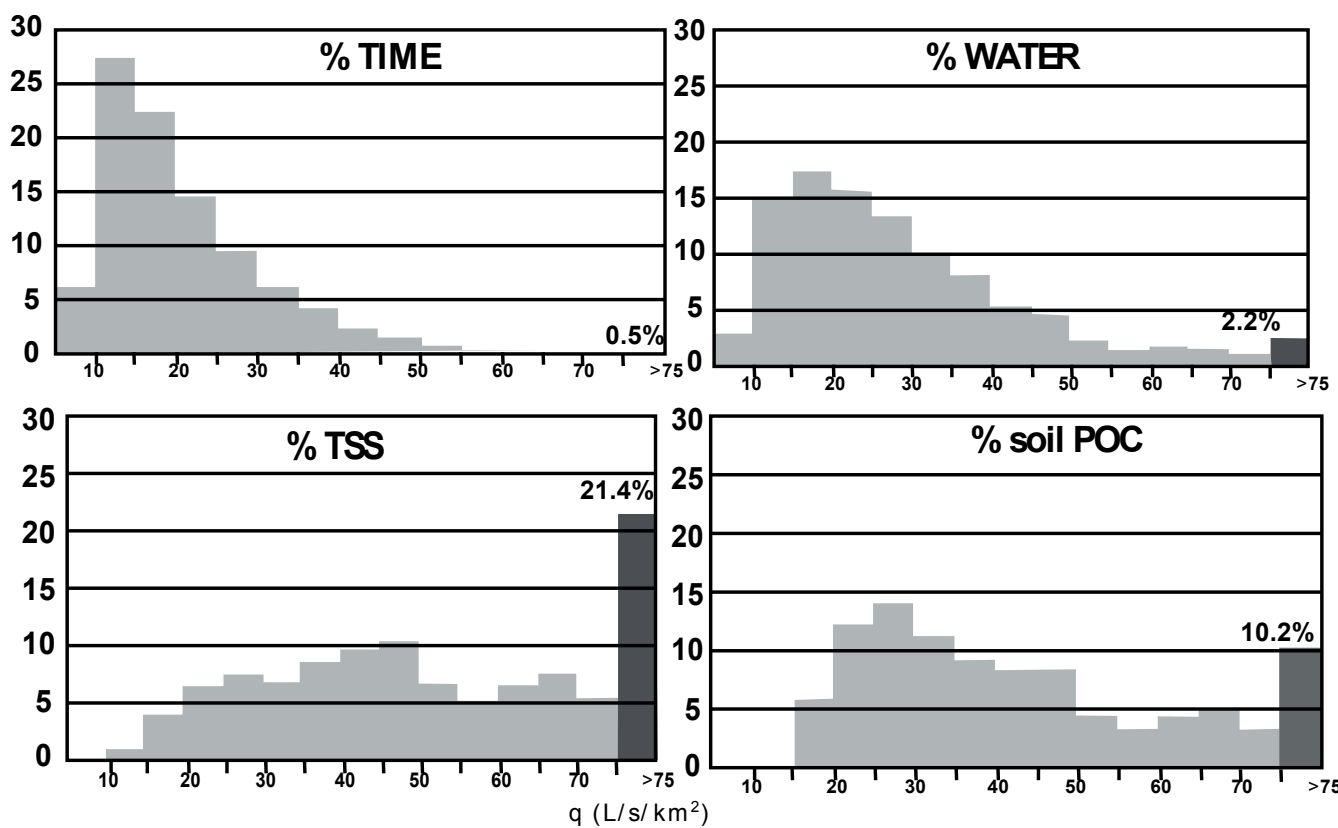

Fig. 9 POC budget in the Rhone River for equal runoff intervals (1994-2004). Distributions of POC fluxes, TSS fluxes, water flow and elapsed time, as \% of their long-term values. 
flow, $0.4 \%$ of TSS flux, and $<0.1 \%$ of POC flux. This example shows that for rivers with extended TSS ranges, POC fluxes should not be estimated by the product of arithmetic POC contents times the sediment fluxes: temporal distributions of both should be combined.

The global POC export by world rivers, much used in global carbon models, also depends highly on river sediment fluxes: it is therefore advisable to break it down into classes of mean river TSS (Meybeck, 1982). The discharge-weighted POC content is much lower than the median or the arithmetic POC contents, often used in global carbon budgets. Therefore, the contribution of fossil POC should be considered at the global scale (Meybeck, 1982).

\section{Control of heavy metal contents by TSS in the impacted Seine and Rhone rivers}

The chemical composition of RPM can be greatly modified by anthropogenic activities, as illustrated for the heavy metals $\mathrm{Cd}, \mathrm{Cu}, \mathrm{Hg}, \mathrm{Pb}$ and $\mathrm{Zn}$ (Meybeck, 2013). Its control by TSS is illustrated here for cadmium in two impacted French rivers, both in the early 1990s: (i) the Seine $\left(65000 \mathrm{~km}^{2}, \mathrm{Y}^{*}=10 \mathrm{t}\right.$ year-1 $\mathrm{km}^{-2}$, median TSS $=30 \mathrm{mg} \mathrm{L}^{-1}$, metal in suspended sediments data from Chiffoleaux et al., 1994; Cossa et al., 1994; Idlafkih et al., 1997) and the Rhone (96000 km², $\mathrm{Y}^{*}=60 \mathrm{t}_{\text {year }}^{-1} \mathrm{~km}^{-2}$, median TSS $=203 \mathrm{mg} \mathrm{L}^{-1}$; metal data from Pont et al., 1996, 2002). In both basins, Cd background contents are low, around $0.2 \mathrm{ppm}$.

Cadmium has been selected here as one of the heavy metals most sensitive to human activities, both for the Seine (Horowitz et al., 1999) and at the global scale (Meybeck, 2013). In the Rhone, the Al content is relatively constant throughout the TSS range (20 to $6000 \mathrm{mg} \mathrm{L}^{-1}$ ). At low flows and turbidities the industrial pollution sources are responsible for a moderate enrichment factor of cadmium in RPM: $\mathrm{EF}_{\mathrm{Cd}}=[\mathrm{Cd} / \mathrm{Al}$ measured $] /[\mathrm{Cd} / \mathrm{Al}$ background $]=5$. In the Seine, the $\mathrm{Al}$ content is highly variable, from $8500 \mathrm{ppm}$ during summer low flows due to the presence of precipitated calcite in this eutrophic river, to $64000 \mathrm{ppm}$ during floods (Idlafkih et al., 1997). The Seine is much more contaminated with metals than the Rhone, with $\mathrm{EF}_{\mathrm{Cd}}>50$ at low flows at this period. At higher TSS, $\mathrm{EF}_{\mathrm{Cd}}$ in the Rhone tends to 1.0 (no enrichment), while it is still around 25 for the Seine samples. The pattern of cadmium contents (ppm or $\mu \mathrm{g} / \mathrm{g}$ ) vs TSS for these pilot surveys (24 samples/year) illustrates these relations (Fig. 10(a)). Some environmental agencies still recommend surveying the metal contamination in rivers on unfiltered waters, expressed in $\mu \mathrm{g} / \mathrm{L}$ or in $\mathrm{ng} / \mathrm{L}$, with the same protocol as other water quality attributes, i.e. at the monthly frequency. This approach greatly under-estimates the average TSS levels and their fluxes (Moatar et al., 2007, 2012), and hence the flow-weighted total concentration of river-borne materials. It also overestimates their weighted contents (\% or ppm of RPM), as seen above for the Rhone POC. The concentration of total cadmium that would result from a complete RPM digestion, expressed in $\mathrm{ng} / \mathrm{L}$, has been simulated for the Seine and the Rhone (Fig. 10(b)). The dissolved Cd in both rivers does not exceed $20 \%$ of total cadmium at low flows and is only few $\%$ at high flows. In both cases,
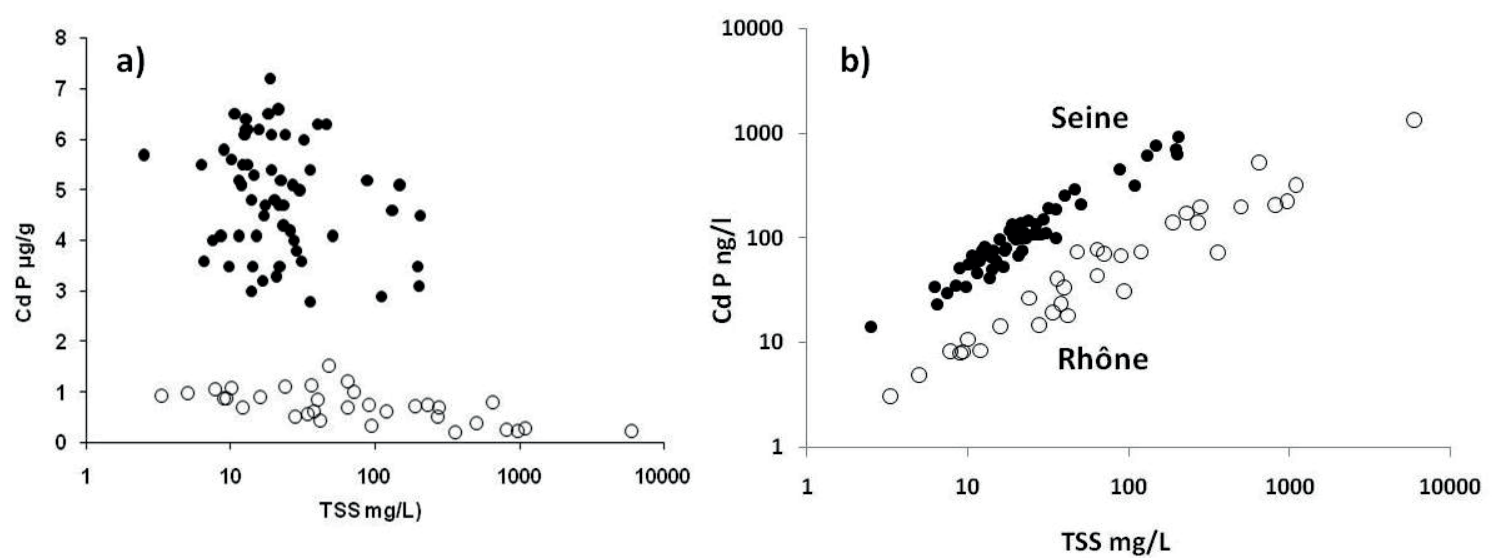

Fig. 10 Cadmium control by TSS in Seine and Rhone Rivers (France): (a) Cd contents ( $\mu \mathrm{g} / \mathrm{g}$ or ppm) in suspended particulates $v$ S TSS; (b) calculated total cadmium concentration (ng Cd/L) vs TSS. 
the total cadmium is completely controlled by the TSS contents and ranges over 2 orders of magnitude for the Seine (10 to $1000 \mathrm{ng} / \mathrm{L}$ ), and over 3 orders for the Rhone. In other words, monitoring total heavy metals on unfiltered samples is just another expensive and inelegant way of monitoring TSS levels. For other TSS-dependent water quality indicators such as TOC, total phosphorus, etc., river quality surveys should combine a limited number of RPM analyses on filters with daily TSS measurements.

\section{GENERAL CONCLUSION AND WAY FORWARD}

The temporal variations of TSS in world rivers at the daily scale can now be addressed by specific metrics, for river runoff, SPM concentrations and for daily fluxes or yields. These dimensionless metrics allow river stations to be compared across and between basins. They also permit intrastation comparisons of these temporal variabilities at different periods, for example, pre- and postdamming conditions. Finally, they can also be used to make comparisons between different types of river material at the same stations (Meybeck \& Moatar, 2012; Moatar et al., 2013). These metrics illustrate the wide range of TSS and of TSS vs q patterns in relation to river hydrology. Other factors controlling daily variability, such as relief, basin erodibility and size, and lake occurrence should now be specified through a generalized use of these metrics.

Two key indicators have been described. First, the sediment flux duration in $2 \%$ of time $\left(\mathrm{M}_{2}\right)$, and secondly the truncated exponent of the sediment rating curve $\left(b_{50 \text { sup }}\right)$. When positive, as for suspended sediments, $b_{50 \text { sup }}$ can be considered as an amplifier for the daily variability indicators of TSS and yields. When daily records are not available, $\mathrm{M}_{2}$ can be estimated with the flow duration metric $\left(\mathrm{W}_{2}\right)$ and $\mathrm{b}_{50 \text { sup. }}$. Similarly, the extreme variability of TSS $\left(\mathrm{C}_{99} / \mathrm{C}_{50}\right)$ and yields $\left(\mathrm{Y}_{99} / \mathrm{Y}_{50}\right)$ can be estimated (Meybeck \& Moatar, 2012). For daily TSS and yields, local basin morphology and size are important factors and should be further investigated. For RPM chemistry, local lithology can be important for stream basins (Meybeck, 2013), and regional means should be preferred, as shown for the USA (Horowitz et al., 2011). Global river averages should be avoided and not used as a reference when considering basin-to-basin variability of TSS levels and yields, their daily temporality and their chemical composition (Meybeck, 2013).

TSS is only a controlling factor of the RPM chemistry of major elements in large tropical basins: lowland RPM are very weathered, i.e. depleted in soluble elements ( $\mathrm{Na}, \mathrm{K}$ and $\mathrm{Mg}$ ), while enriched in the least soluble elements (Al, Fe, Ti) compared to highland RPM, whose chemical compositions remain close to those of parent rocks. In contrast, the POC contents are always controlled by TSS concentrations. Therefore, the river survey for particulate chemistry should cover the whole TSS range so that chemistry $v s$ TSS relationships can be checked and used to compute river fluxes. The arithmetic averages or medians of RPM analyses may be quite different from the sediment discharge-weighted means. Furthermore, TSS flux variability has a direct consequence on water quality surveys for total materials (organic carbon, TOC), and total nutrients such as TKN, and total metals, often recommended by water authorities and environmental agencies because total concentrations on unfiltered samples always depend directly on TSS. Moreover, these surveys are generally performed at a monthly frequency, in which turbid flood episodes are rarely documented. Total nutrients and TOC fluxes can therefore be largely underestimated if flux calculation methods do not take into account TSS variability (Raymond et al., 2012; Moatar et al., 2013).

Human activities profoundly modify the natural picture, as demonstrated by the impact of river damming on daily variability metrics and the relationship between heavy metal contents and TSS in impacted basins. We are still very far from having a correct picture of world rivers in the current Anthropocene era (Meybeck, 2003b; Vörösmarty et al., 2010).

Acknowledgements This work has greatly benefited from previous studies and discussions with our colleagues: James Syvistki, Charles Vörösmarty, Arthur Horowitz, Zahid Idlafkih, Cécile Grosbois, Alexandra Coynel and has benefited from data generated by Jérome Gaillardet, Vladimir Gordeev, Jean Loup Guyot, Daniel Cossa, Richard Semperé and Didier Pont. It has been financed by the national ECCO programme (VARIFLUX and VARIQUAL projects) of the CNRS. 


\section{REFERENCES}

ASCE Task Committee (1970) Sediment sources and Sediment yields. Am. Soc. Civil. Eng. Hydraulics Div. J., 7337, $1283-1329$.

Canfield, D.E. (1997) The geochemistry of river particulates from the continental USA: major elements. Geochimica et Cosmochimica Acta 61, 3349-3365.

Chiffoleau, J.F., et al. (1994) Trace metal distribution, partition and fluxes in the Seine estuary (France) in low discharge regime. Marine Chemistry 47, 145-158.

Cossa, D., et al. (1994) Etude pilote des apports en contaminants par la Seine. Agence de l'Eau Seine-Normandie, Min. Environnement, Ifremer-Nantes Rpt Interne Del/94-13, 151pp.

Coynel, A, et al. (2005). Spatial and seasonal dynamics of total suspended sediment and organic carbon species in the Congo River. Global Biogeochemical Cycles 19(4). doi: 10.1029/2004 GB002335

Degens E.T., Kempe S. \& Richey J.E. (eds) (1991) Biogeochemistry of World Major Rivers. SCOPE 42, Wiley, New York, $356 \mathrm{pp}$

Dunne T. (1979) Sediment yield and land use in tropical catchments. J. Hydrol., 42, 281-300

Gaiero, D.M., et al. (2002) Riverine transfer of heavy metals from Patagonia to the South Western Atlantic Ocean. Reg. Env. Change 3, 51-64.

Gaillardet, J., B. Dupré, et al. (1997) Chemical and physical denudation in the Amazon River basin. Chemical Geology 142, $141-173$

Gaillardet, J., Dupré, B. \& Allègre, C.J. (1999) Geochemistry of large rivers suspended sediments: silicate weathering or recycling tracer? Geochem. Cosmoch. Acta, 63, 4037-4051.

Gaillardet, J., Millot, R. \& Dupré, B. (2003) Chemical weathering rates of the western Canadian orogenic belt: the Stikine terrane. Chemical Geology 201(3-4), 257-279.

Gordeev, V. \& Lisitzin, A.P (1978) Average chemical composition of suspended matter in world rivers and river inputs to the oceans. Dokl.Akad. Nauka SSSR, 238, 225-228 ( in Russian).

Guyot, J.L. (1992) Hydrogéochimie des fleuves de l'Amazone bolivienne. Thèse Univ. Bordeaux 1, 350p.

Humphreys, A.A. \& Abott, H.L. (1861) Report on the Physics and Hydraulics of the Mississippi River. US Bureau of Topographical Engineers Prof. Paper 4, Lippincott, Philadelphia, 460pp and Appendices.

Horowitz, A.J., et al. (1999) Variations in trace elements geochemistry in the Seine River basin based on floodplain deposits and bed sediments. Hydrol. Processes 13, 1329-1340.

Horowitz, A.J., Elrick, K.A. and Smith, J.J. (2001) Annual suspended sediment and trace element fluxes in the Mississippi, Columbia, Colorado and Rio Grande drainage basins. Hydrol. Processes 15, 1169-1207.

Horowitz, A. (2003) An evaluation of sediment rating curves for estimating suspended sediment concentrations for subsequent flux calculations. Hydrol. Processes, 17(17), 3387-3409

Horowitz,A.J., et al.. (2011) Concentrations and annual fluxes of sediment-associated chemical constituents from conterminous US coastal rivers using bed sediment data. Hydrol. Processes doi: 10.1002/hyp.8437

Idlafkih Z., et al. (1997) Comportement des métaux particulaires (Al, Fe, Mn, Cd, $\mathrm{Cu}, \mathrm{Hg}, \mathrm{Pb}, \mathrm{Zn}$ ) dans la Seine à Poses en période de hautes eaux (1990-1995). In: Freshwater Contamination (ed. by B. Webb), IAHS Publ. 243, 45-58.

Kao, S.J. \& Liu, K.K. (1997) Fluxes of dissolved and non-fossil particulate organic carbon from an Oceania small river (LanyanHsi) in Taiwan. Biogeochemistry 39, 255-269

McLennan, S.M. \& Murray R.W. (1999) Geochemistry of sediments. In: Encyclopedia of Geochemistry (ed.by C.P. Marshall \& R. W. Fairbridge), Kluwer, 282-292.

Malcolm, R.L. \& Durum, W.H. (1976) Organic carbon and nitrogen concentrations and annual organic carbon load of six selected rivers of the United States. US Geol. Survey. Water Supply Paper1817-F, Reston, Virginia.

Martin, J.M. \& Meybeck, M. (1979) Elemental mass-balance of material carried by major world rivers. Marine Chem. 7, $173-206$.

Meade, R.H. \& Parker, R.S. (1985) Sediments in rivers of the United States. US Geological Survey Water Supply Paper 2275: 49-60.

Meybeck, M. (1982) Carbon, nitrogen and phosphorus transport by world rivers. American. J. Science 282,401-450.

Meybeck, M. (2003) Global occurrence of major elements in rivers. In: Treatise on Geochemistry, Vol. 5 (ed. by J.I. Drever). Elsevier Science, 207-223.

Meybeck, M. (2006) Origins and behaviors of carbon species in world rivers. In: E.J. Roose et al.(eds) Soil Erosion and Carbon Dynamics. Adv.Soil Sci. Series, CRC,Bocca Raton, 209-238.

Meybeck, M. (2013) Heavy metal contamination across the globe, an indicator of complex interactions between societies and catchments. In: Understanding Freshwater Quality problems in a Changing World. (ed. by B. Arheimer et al.). IAHS Publ. 361, 3-16.

Meybeck, M. (2014) The chemical composition of particulate matter transported by the world's major rivers. In: World Large Rivers (ed. by H. Habersack and D. Walling), Wiley (in press).

Meybeck, M. and Ragu A. (1997) River discharges to the Oceans: an assessment of suspended solids, major ions and nutrients. UNEP/WHO, GEMS-Water, 245pp.

Meybeck, M., et al. (2003) Global variability of daily total suspended solids and their fluxes in rivers. Global and Planetary Change 39, 65-93.

Meybeck, M. and Moatar. F. (2012) Daily variability of river concentrations and fluxes: indicators based on the segmentation of the rating curve. Hydrol. Processes, 26, 1188-1207.

Meybeck, M., Kummu, M. and Dürr, H.H. (2013) Global hydrobelts and hydroregions:improved reporting scale for water related issues? Hydrol. Earth Syst. Sci. 17, 1093-1111. doi:10.5194/hess-17-1093-2013.

Milliman, J.D. \& Syvitski, J.P.M. (1992) Geomorphic/tectonic control of sediment discharge to the ocean: the importance of small mountainous rivers. The Journal of Geology 100, 525-544.

Milliman, J.D. \& Farnworth, K.L. (2011) River Discharge to the Ocean: A Global Synthesis. Cambridge Univ. Press, 384 pp.

Moatar, F., et al. (2006) The influence of contrasting suspended particulate matter transport regimes on the bias and precision of flux estimates. Science of the Total Environment 370, 515-531. 
Moatar, F., et al. (2013) River flux uncertainties predicted by hydrological variability and riverine material behavior. Hydrol. Processes 27, 3535-3546, doi: 10.1002/hyp.9464.

Moreira-Turcq P., et al. (2003) Exportation of organic carbon from the Amazon River and its main tributaries. Hydrol. Processes, 17, 1329-1344.

Nash, D. B. (1994) Effective sediment-transporting discharge from magnitude-frequency analysis, The Journal of Geology, 102, 79-95.

Pont, D., Simonnet, J-P. \& Walter, A.V. (2002) Mid-term changes in suspended sediment delivery to the ocean: consequences of catchment heterogeneity and river management (Rhône River, France). Est. Costal Shelf Sci., 54, 1-18.

Pont, D., et al. (1996) Evaluation des charges polluantes à la Méditerranée. Rapport final à l'Agence de l'Eau RhôneMéditerranée-Corse et à la région Provence-Alpes-Côte d'Azur.

Potter, P.E. (1978) Petrology and chemistry of modern big river sands. J. Geology, 86, 423-449.

Rachold, V. (1999) Major, trace and Rare Earth Elements geochemistry of suspended particulate material of East Siberian Rivers draining into the Arctic Ocean. In: Land-Ocean Systems in the Siberian Arctic (ed. H. Kassens), Springer, 199-222.

Raymond, S., et al. (2013) Choosing methods for estimating dissolved and particulate riverine fluxes from monthly sampling. Hydrological Sciences Journal 58 (6), 1-14.

Reimann, C. \& de Caritat, P. (1998) Chemical Elements in the Environment. Springer, 398 pp.

Savenko, V.S. (2007) Chemical composition of world's suspended matter. Geochem. Int. 45(8), 816-824.

Sempéré, R., et al. (2000) Carbon inputs of the Rhône River to the Mediterranean Sea: biogeochemical implications. Global Biogeochem. Cycles 14, 669-681

Syvitski, J.P. \& Morehead, M.D. (1999) Estimating river-sediment discharge to the ocean: application to the Eel margin, northern California. Marine Geology 154, 13-28

Syvitski, J.P.M., et al. (2005) Impacts of humans on the flux of terrestrial sediment to the global coastal oceans. Science 308, $5720,376-380$.

Viers, J., Dupré, B. \& Gaillardet, J. (2008) Chemical composition of suspended sediments in world rivers: new insights from a new data base. Science of the Total Environment 407(2), 853-868

Vörösmarty, J.V., et al. ( 2003) Anthropogenic sediment retention: major global impact from registered river impoundments. Global Planetary Changes 39(1-2), 169-190.

Vörösmarty, C.J., et al. (2010). Global threats to human water security and river biodiversity. Nature 467, 555-561.

Walling, D.E. (1977) Suspended sediments and solute response characteristics of the River Exe, Devon, England. In: R. Davidson-Arnott and W. Nickling (eds), (1996) Research in Fluvial Geomorphology. GeoAbstracts, Norwich, UK, 169-197.

Walling, D.E. \& Webb, B.W. (1996) Erosion and sediment yield: a global overview. In: Erosion and Sediment Yield: Global and Regional Perspectives (ed. by Walling, D.E. \& Webb, B.W.). IAHS Publ. 236, 3-19. 